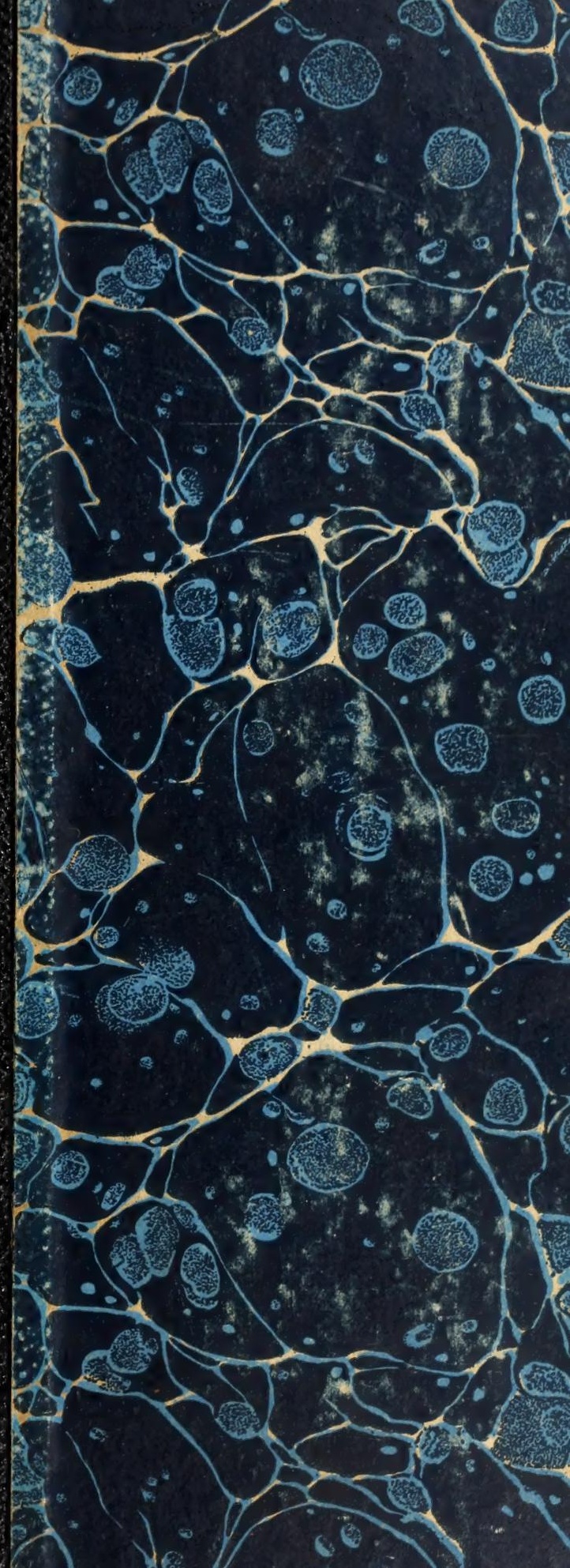





\section{Historic, archived document}

Do not assume content reflects current scientific knowledge, policies, or practices. 



\title{
UNITED STATES DEPARTMENT OF AGRICULTURE
}

\section{BULLETIN No. 1021}

Contribution from the Bureau of Plant Industry

WM. A. TAYLOR, Chief

Washington, D. C. PROFESSIONAL PAPER

April 17, 1922

GROUP CLASSIFICATION AND VARIETAL DESCRIPTIONS OF AMERICAN VARIETIES OF SWEET POTATOES

\author{
By
}

H. C. THOMPSON, formerly Horticulturist, and JAMES H. BEATTIE, Horticulturist, Office of Horticultural and Pomological Investigations

\section{CONTENTS}

Importance of Varietal Classification of

Sweet Potatoes ..........

Early Attempts at Classification . . . .

Propesed System of Classification ...

Key to the Groups ..........

Deseriptions of the Groups ......
Page

List of Varieties Included in the Key . Descriptions of Varieties . . . . . . Check List of Names Used in SweetPotato Literature . . . . . . . 18 Bibliography of Sweet-Potato Literature .............. 26 



\section{UNITED STATES DEPARTMENT OF AGRICULTURE}

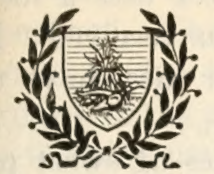

\section{BULLETIN No. 1021}

Contribution from the Bureau of Plant Industry WM. A. TAYLOR, Chief.

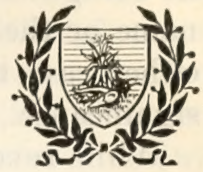

Washington, D. C.

\section{GROUP CLASSIFICATION AND VARIETAL DE- SCRIPTIONS OF AMERICAN VARIETIES OF SWEET POTATOES. ${ }^{1}$}

By H. C. Thompson, formerly Horticulturist, and James H. BeatTie, Horticulturist, office of Horticultural and Pomological Investigations.

\section{CONTENTS.}

Importance of varietal classification of sweet potatoes

Early attempts at classification Proposed system of classification -.. Key to the groups

Descriptions of the groups Ticotea group Belmont group Spanish group Shanghai group Florida group -

Page.

1
2
4
6
6
6
7
8
8
9

\section{Description of the groups - Contd.} Southern Queen group _________ 9

Pumpkin group

Jersey group 10

List of varieties included in the key $\quad 11$

Descriptions of varieties_._._. 11

Check list of names used in sweetpotato literature

Bibliography of sweet-potato literature -...-.
Page.

\section{IMPORTANCE OF VARIETAL CLASSIFICATION OF SWEET POTATOES.}

To those familiar with the present state of sweet-potato nomenclature it is apparent that there is need for some simple system of classification by which varieties may be identified well enough to place them in the groups to which they belong. The need for such a classification is clearly shown by the large number of new names that each year are given to old varieties. The need is also readily

1 Credit for the description of many of the varieties of sweet potatoes and for the working out of the system of classification contained in this bulletin is due F. J. Tyler, formerly assistant in botany of the Bureau of Plant Industry.

The main portion of the work was done by Mr. Tyler between 1902 and 1906 ; the addition of a number of important varieties not studied by Mr. Tyler and further work on all the varieties has necessitated changes in the key and in some of the descriptions.

During the progress of these investigations considerable work has been done by W. R. Beattie, horticulturist; Ghester J. Hunn, assistant horticulturist; and H. M. Conolly, formerly assistant horticulturist, Office of Horticultural and Pomological Investigations, Bureau of Plant Industry. 
seen from a study of the literature on sweet potatoes. There being no recognized system of classification, the investigator uses a local name or the name under which the sweet potato was received. In either case the name may be entirely misleading or may have no significance.

While several hundred names are given to varieties of sweet potatoes grown in the United States, there are not over 40 true varieties. Not more than 10 of these varieties are of commercial importance, and 4 of them constitute the bulk of the commercial crop. Some of the important varieties are known under many different names. The Southern Queen, for example, is known under at least 20 different names, although Southern Queen and Hayman are by far the most common. Probably 90 per cent of the growers of this variety know it under one of the two names mentioned. Even such a well-known variety as Yellow Jersey is known under at least 10 names.

Giving new names to old varieties is very common, but is very confusing. In many cases the giving of a new name to an old variety is done because the true name is not known, but in other cases the new name is given for the purpose of deception. When a grower receives a sweet potato which is not known to him, he should make every effort to learn the correct name and not give it a name of his own choosing. There is certainly no excuse for renaming such wellknown varieties as Southern Queen and Yellow Jersey, but it is the best-known varieties that have the greatest number of names.

To set forth a simple system of classification of sweet-potato varieties that will be of help to investigators, teachers, and growers is the purpose of this bulletin.

\section{EARLY ATTEMPTS AT CLASSIFICATION.}

The earliest important attempt at classifying the varieties of sweet potatoes was made by R. H. Price(55), ${ }^{1}$ of the Texas Agricultural Experiment Station. Under this system sweet potatoes are classified into three groups based on the shape of the leaves, as follows:

(1) Varieties with entire or round foliage.

(2) Varieties with shouldered foliage.

(3) Varieties with deeply cut or lobed foliage.

After classifying sweet potatoes into the three groups by the typical shape of the leaves, each variety is described separately, but as no key is given except that referring to the shape of the leaves, it is not possible to determine a variety if the name is doubtful or unknown. The procedure to follow under this system is first to deter-

1 The serial numbers in parentheses refer to the "Bibliography of sweet-potato literature" at the end of this bulletin. 
mine to which of the three groups a given specimen belongs and then to read the descriptions of varieties until one is found which fits the specimen. This is a tedious and cumbersome method, although great credit is due the originator of this system, for it introduced some order into the previous chaotic condition. It is not possible, however, to identify many varieties without taking into consideration many points other than the shape of the foliage. The description given to the varieties is not sufficient to identify most varieties now grown.

Another classification of sweet-potato varieties that has been published is the one worked out by Groth(26). In this system the following factors are considered in making the key:

A. Shape of leaf.

(1) Cut.

(2) Round.

(3) Long.

(4) Broad.

(5) Mixed (round and lobed).

$B$. Size of leaf.

(1) Small (less than 4 inches across) .

(2) Large (more than 4 inches across).

c. Length of stem.

(1) Long (more than 4 feet long).

(2) Short (less than 4 feet long).

D. Color of stem.

(1) Green (with or without brownish areas).

(2) Green (with purple around the axils of the leaves).

(3) Greenish brown to purple.

(4) Purple.

$E$. Size of stem.

(1) Thin (less than one-eighth of an inch in diameter).

(2) Thick (more than one-eighth of an inch in diameter, often three-sixteenths or more).

$F$. Presence or absence of star.

(1) Star present.

(2) Star absent.
$G$. Color of lower surface of veins.

(1) Vein purple.

(2) Midrib pinkish in some old leaves.

(3) Purple spot at base of midrib.

(4) Veins all green.

$H$. Arrangement of hair on the upper surface of the leaf, if any.

(1) Hair all over.

(2) Chiefly on tips and along veins.

(3) Absent.

I. Outside color of the roots.

(1) White.

(2) Yellow, golden, or bronze.

(3) Yellow, red, or pinkish.

(4) Red or purple.

$J$. Color of flesh of the roots.

(1) White.

(2) Cream colored or yellowish white.

(3) Pinkish white or pinkish yellow.

(4) Pinkish orange.

(5) Marked with purple.

$K$. Distinctness of wood elements in the root.

(1) Distinct.

(2) Blurred.

(3) Not visible.

While most of these characteristics are very important, some of them vary so much under different environmental conditions that their use in a key is of doubtful value. The size of the leaf and size and length of the stem vary so much under different soil and climatic conditions that measurements made under one set of conditions do 
not fit under different conditions. It is well known that the length of vine of any variety is greater in the South than in the North. The length and size of the vine, as well as the size of the leaf, are greater on heavy soils than on light sandy soils. In the description of the Nancy Hall variety the stem is classed as short (under 4 feet long), while in practically every region where this variety is grown to any great extent the stem grows to be more than 4 feet in length. In the vicinity of Washington, D. C., on a sandy-loam soil the stems grow 4 to 8 feet long. The vine of the Shanghai variety is also classed as short, but under the conditions mentioned in connection with the Nancy Hall it grows to be 6 to 9 feet in length. The stems of the Ticotea and Florida varieties are also classed as short, while under fairly favorable conditions they grow to a length of 6 to 9 or 10 feet.

The other characters used in the key, with the possible exception of the "Arrangement of hair on the upper surface of the leaf, if any," and "Distinctness of wood elements in the root," are very important and reliable. All characters should be considered in connection with the mature plant, as many do not develop on new growth and some disappear as the plant nears maturity. The shape of the leaves on new growth is often very different from the shape of fully developed leaves. The surface of young leaves may be covered with hairs, while older leaves may be entirely smooth. The use of letters and numbers rather than the terms for which they stand makes the key rather awkward.

Another attempt at classification of sweet-potato varieties is given in Bulletin 33, "Estacion Experimental Agronomica," Santiago de las Vegas, Cuba, entitled "Las Variedades Cubanas de Boniato." This work deals to a certain degree with American varieties, much of the material having been obtained in this country. In this system of classification four groups-white, yellow, purple, and reddishare made, and these are further divided according to the color of the stems, leaves, and veins on the leaves. This system of classification is not sound, as the color of the roots varies greatly with difference in soil and climatic conditions.

\section{PROPOSED SYSTEM OF CLASSIFICATION.}

The work on which the proposed system of classification is based was begun by the Bureau of Plant Industry in 1901 and has been continued up to the present time. During the season of 1901 the varietal work was carried on at College Park, Md., in cooperation with the Maryland Agricultural Experiment Station. At the end of the season, the work and the varietal collection were transferred to the Bureau of Plant Industry. From 1902 to 1920 the collection has been grown every year on the Potomac Flats, near Washington. The 
soil selected has ranged from sand to a fine sandy loam. Most of the studies have been made from the crops grown at Washington, but the varieties have also been grown at Baton Rouge, La.. Florence, S. C., Norfolk, Va., Columbus. Ohio, and Watson, N. Y., for the purpose of studying their behavior under different environments. 'The varietal descriptions were checked with the collections grown at all of the points mentioned.

During the years the work has been in progress it has been the aim to test all varieties that are grown in the United States. New varieties have been added from time to time, and many so-called new varieties have been grown, only to find that they were old varieties given new names. It is believed that practically all varieties now grown in the United States are included in the present collection. All the important sweet-potato growing regions have been visited by those engaged in the work, and wherever a variety was found which was not definitely known it was added to the collection for study and comparison with the varieties being grown in the test.

Before attempting to classify the varieties of sweet potatoes, careful descriptions were made of all varieties. Those showing a marked similarity were grouped together in the field for further comparison. It has been found that all the varieties that have been grown can be placed in eight well-defined groups, each group being distinct and easily recognized. By means of a simple key, the group to which any variety belongs can be determined very easily and quickly. Each group has been given the name of the most widely known variety or the variety that is most typical of that group. Three of the large groups have been divided into sections to simplify the procedure of identification. It is believed that this grouping of varieties makes iclentification comparatively easy. After determining the group to which a rariety belongs by means of the key the group description shonld be read to determine the section and the variety. To make sure of the correctness of identification, the descriptions of all varieties in the group should be read.

As indicated in previous pages, no one character can be depended on to establish the identity of any sweet-potato variety; but rather a combination of characters, such as the length and character of the vines and the size, shape, and color of the roots. While typical specimens of such rarieties as the Porto Rico, Big-Stem Jersey, Nancy Hall, Triumph, Yellow Strasburg, Southern Queen, and Pumpkin may be described as fusiform to globular, long fusiform,. fusiform, medium to long cylindrical, globular, or ovoid in shape, an inspection of Plates I, II, and III, which show the variation in the size and the shape of several specimens of each of these varieties, will show how great the variations in size and shape within the variety really are. 
In giving the names of the rarieties it would be desirable to consider priority of nomenclature, but it is not possible to establish priority. In most cases it has not been possible to determine when, where, and by whom a name was given; therefore it has been deemed advisable to select the name that is in most general use. It is realized that growers in some sections will feel that some of the names used in this bulletin are not the correct ones. Growers in Viriginia may insist that the name Hayman should have been used instead of Southern Queen, but the latter name is more common in all other sweet-potato growing regions. The name Nansemond is more common than Yellow Jersey in Virginia, but the latter name is much more common in all other regions where this rariety is grown. The same may be said of all other names selected to designate the important varieties. Some rarieties are grown to such a limited extent that there is not much chance for confusion.

\section{KEY TO THE GROUPS.}

I. Leaves deeply lobed or parted-1 and 2 .

(1) Leaves with purple stain at the base of the leaf blades.

(2) Leaves without purple stain at the base of the leaf blades.

Ticotea, page 6 .

BELMONT, page 7 .

II. Leaves not deeply lobed or parted-1 and 2 .

(1) Leaves with purple stain at the base of the leaf blades_ $A$ and $B$.

(A) Stems purple or greenish with decided tinge_-_-_SPANisH, page 8.

(B) Stems- $a$ and $b$.

(a) Leaves entirely to slightly shouldered; roots white.

S'Hanghai, page 8 .

(b) Leares toothed with 6 to 10 low marginal teeth, or entire; roots salmon or yellow tinged with salmon.

Florida, page 9.

(2) Leaves without purple stain at the base of the blade or with very faint stain- $A$ and $B$.

(A) Stems purple

(B) Stems green- $a$ and $b$.

(a) Stems medium to large in size; roots fusiform, yellow tinged with salmon, with light yellow reins__PuMpkin, page 9.

(b) Stem slender; roots russet yellow or red, ovoid to fusiform

JERSEY, page 10.

\section{DESCRIPTIONS OF THE GROUPS.}

In the descriptions of the groups an effort has been made to give the characteristics of the rines and roots of the entire group and not that of any particular variety; in fact, the group description has been made from the descriptions of the varieties belonging to the group.

\section{TICOTEA GROUP.}

Vines long. 6 to 12 feet, or short and stocky; stems green in color or with a tinge of purple at the nodes, nearly smooth; leaves very angular in outline, 5 to 7 lobed; blade hairy only on the veins of the upper surface. green except 
for a deep purple stain at the base of the blade and the summit of the petiole; the latter otherwise grem. hairy, or nearly smooth. Roots white, smooth, without veins or ribs, varying from fusiform to cylindrical in shape, of medium to large size: flesh white, but dull or grayish white or light yellow when baked, only slightly sweet, quite dry and mealy, and firm in texture. Flavor not pronounced.

The Tieoteal group contains only two varieties, Ticotea and Koali, and is not important.

\section{BELMONT GROUP.}

Vines medium to long, 4 to 12 feet, or very short, 1 to $3 \frac{1}{2}$ feet; stems slenter wr thick and coarse, green, hairy, or smooth to nearly smooth; leaves deeply i to 7 lobed, upler surfice of blade hatiry to nearly smooth, lower surface smooth or slightly hairy along the wins. green in color; petiole also green, hairy, of smooth. Roots light salmon, yellow tinged with salmon, russet yellw, or rose to purple: reins often prominent and always lighter in color than the rest of the surface; the roots usually fusiform, smooth except for the veins, of average size; medium to late in season; flesh white, yellow, light salmon to dark salmon in color, but light yellow, dark yellow, or yellow tinged with salmon when baked, sweet to rery sweet. and so moist that sirup can be squeezed ont with slight pressure; flavor somewhat squashlike; texture soft or at times rather coarse and stringy.

The Belmont group may be divided into two sections, as follows •

Belmont section: Vines long and creeping.

Bunch section: Vines very short and bushy.

The stems of the varieties of the Belmont section are long and slender, from 6 to 12 feet in length; or medium in length, 4 to 8 feet, with internodes 2 to 4 inches long. The leaves are rather small, with narrow lobes, except that those of the Eclipse Sugar "yam" and Vineless Pumpkin "yam" are larger, with broad ovoid lobes.

The following varieties belong to the Belmont section:

(1) Belmont. (This variety or very slight variations of it is known under the names Georgia and Dunton's Improved.)

(2) Eclipse Sugar "yam."

(3) Vineless Punpkin "yam." (Pl. IV, figs. 1 and 2.)

(4) Old Time "yam."

(5) Yellow "yam."

(6) White Sealy.

The stems of the Bunch section are thick and coarse and from 1 to $3 \frac{1}{2}$ feet lons, with internokles one-thirl to one-half an inch long, the leaves being Ereatly crowderl in consequence, and it follows that the total leaf surface of a Bunch vine 18 inches lone is nearly or quite equal to that of a Belmont vine 11 to 12 feet in length. The leares resemble those of the Eelipse variety in being large, with broad oroid lobes.

The following varieties belong to the Bunch section:

(1) Gros Grandia.

(2) Bunch ('ancly "yam." (Also called Bunch "yam," Vineless, Prolific, and (rold Coin.) (Pl. IV, fig. 3.)

\footnotetext{
1 The term "yam" used in this key to designate certain varieties of sweet potatoes is used because it is a varietal designation and not because it refers to a yam. The term "yam" when applied to sweet potatoes is a misnomer, as the true yams belong to an entirely different genus, Dioscorea. Yams are grown to a limited extent only in the more southerly portions of the South, principally Florida, and are of little commercial importance.
} 


\section{SPANISH GROUP.}

Vines medium in length, 4 to 10 feet or 6 to 15 feet long (vines of Red Brazil and Creola sometimes grow to be 20 feet long), or short and bushy, 2 to 3 feet, coarse, clark purple in color or green with purple tinge, hairy (especially at the nodes) or smooth; leares deeply shouldered to entire, green except for a deep purple stain at the base of the blade and the summit of the petiole. The color may extend up the reins, hairy on the upper surface or only on veins, or smooth, the under surface smooth or slightly hairy; petiole green tinged with purple toward the summit, or deep purple. Roots red, sellow, russet yellow, or sellow tinged with rose, usually rery irregular, being strongly ribbed and reined or smooth; fusiform, oroid, or long cylindrical in shape; medium to very large in size, ripening either early or late. Flesh white, yellow, dull yellow, cream, salmon sellow, or dark sellow. When baked, sightly sweet to rery sweet, moist to dry and mealy, firm or soft in texture. Flavor caramellike, but not pronounced.

The varieties in the Spanish group may be separated into three sections, as follows :

(1) Yellow Spanish: Roots light yellow to russet yellow.

(2) Bermuda: Roots light yellow, yellow tinged more or less with rose or deep rose.

(3) Red Spanish: Roots dark red to purple.

In the Yellow Spanish section the roots are light yellow in color, usually very irregular, strongly ribbed and reined, but sometimes fairly smooth and regular; flesh white or yellow. The earliest varieties are contained in this section, being listed as follows:

(1) Pierson. (This same variety or variations of it is known under the names of Arkansas Beauty, California Golden, Early General Grant, Golden Skin, and Dutton's Early.)

(2) Yellow Strasburg. (Also called Extra Early Golden and Adams.) (Pl. IV, fig. 4, and Pl. V, fig. 1.)

(3) Yellow Spanish. (Also called Bronze Spanish.)

(4) Triumph.

The roots of the Bermuda section are light yellow, more or less orerlain with transverse dashes and bands of rose, sometimes washed with rose, or deep rose to purple, usually very irregular, strongly ribbed and veined; but some varieties are quite smooth and regular. The varieties are medium early, being listed as follows :

(1) Red Bermuda. (Also known as Cuba "yam," Poreland, Yellow Red.)

(2) Red Brazil or Red Brazilian.

(3) Porto Rico. (Also called Golden Beauty and Key West "yam.")

(4) Key West "yam."

(5) Creola.

Roots of the Red Spanish section are more regular and are not constricted; the flesh is white, tingel with purple beneath the skin and at the center. The section contains the following varieties:

(1) Red Spanişh. (Also called Black Spanish.)

(2) Purple "yam," or Nigger Choker.

(3) Dahomey.

\section{SHANGHAI GROUP.}

Vines medium to long, 5 to 10 feet, or long, 8 to 16 feet; stems coarse and thick, green in color and hairy, especially at the nodes; leares large, entire, or sometimes shouldered, hairy at first, but later smooth except for scattered hairs 
But. 1021, U. S. Dept. of A riculture.

PLATE I - -
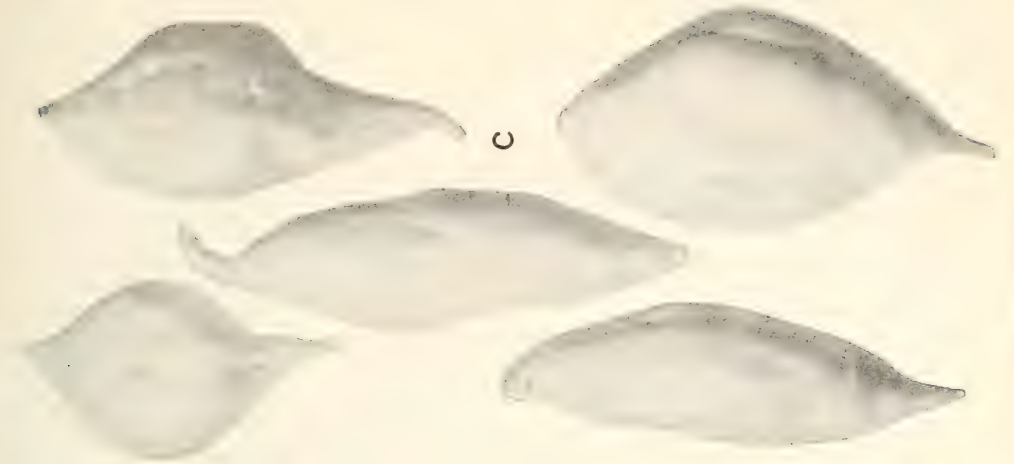

$\underline{\underline{E}}$
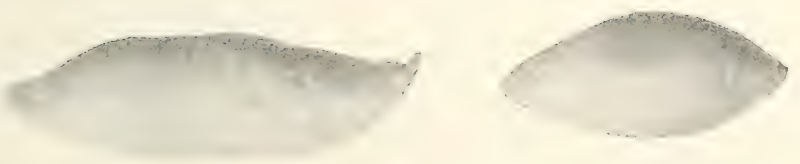

$\infty$
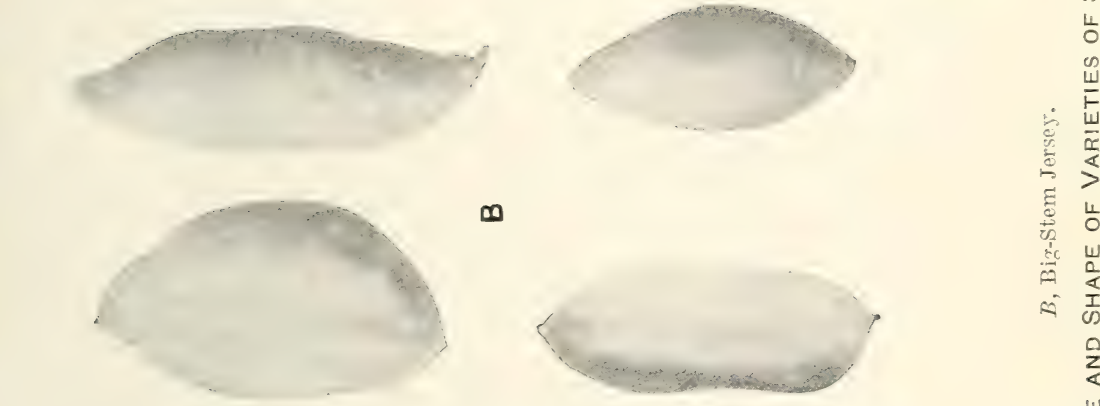

$$
\begin{aligned}
& \text { 봉 }
\end{aligned}
$$

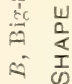$$
\therefore \text { U. }
$$$$
\text { 学 }
$$

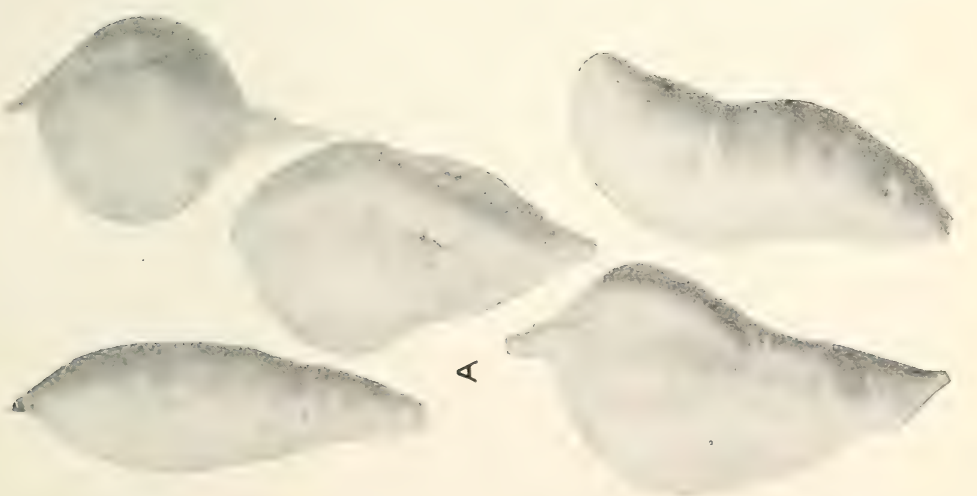



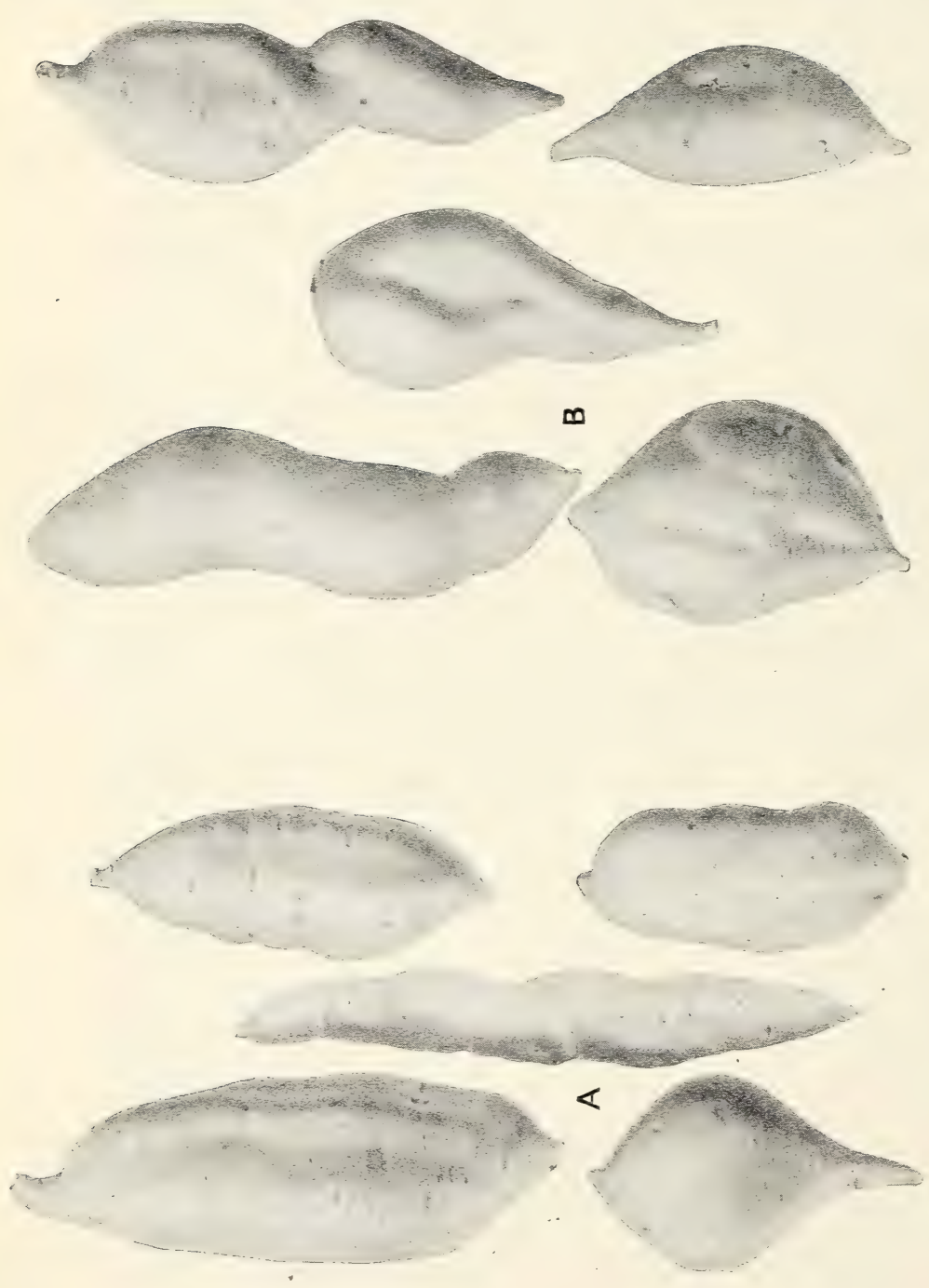

$\sum_{<}^{0}$ 

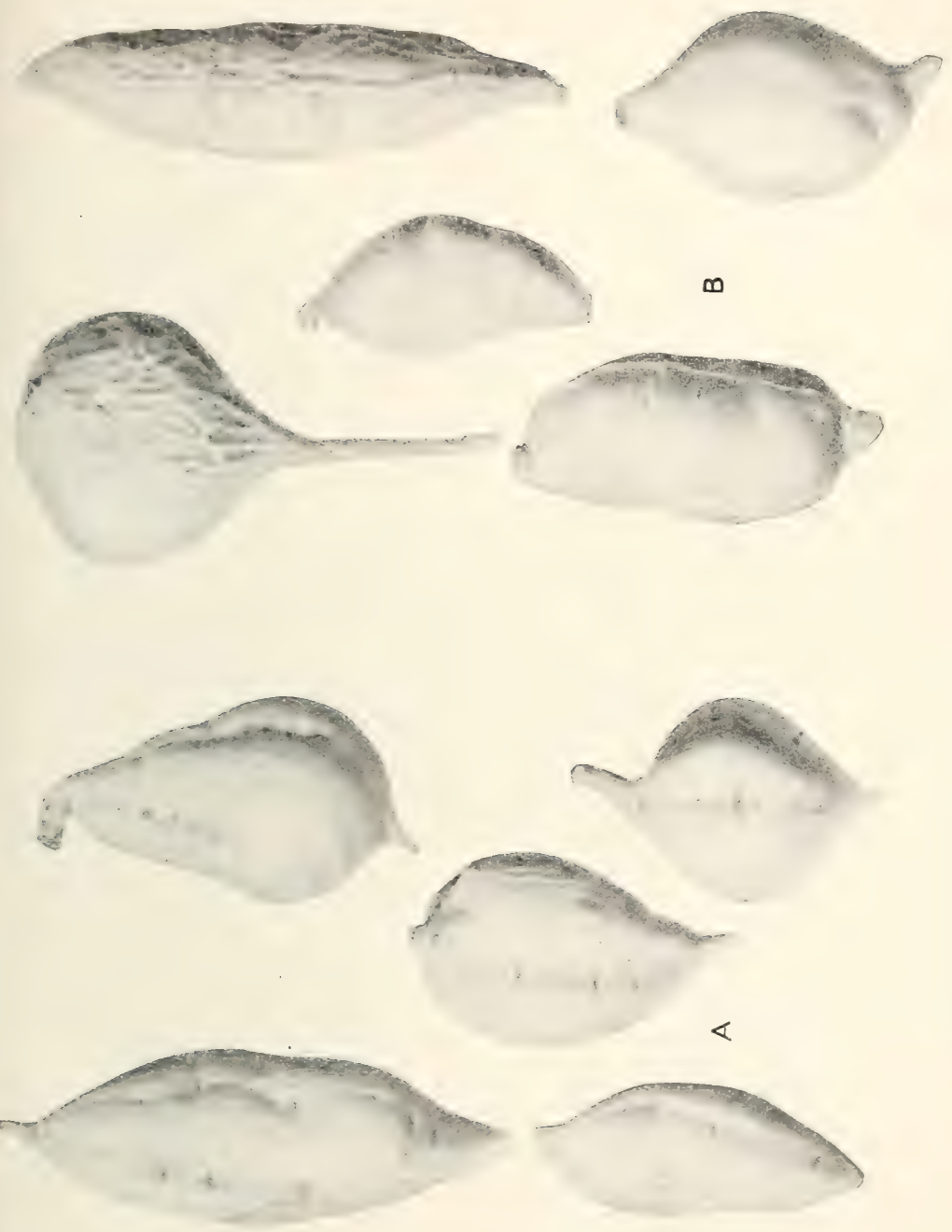


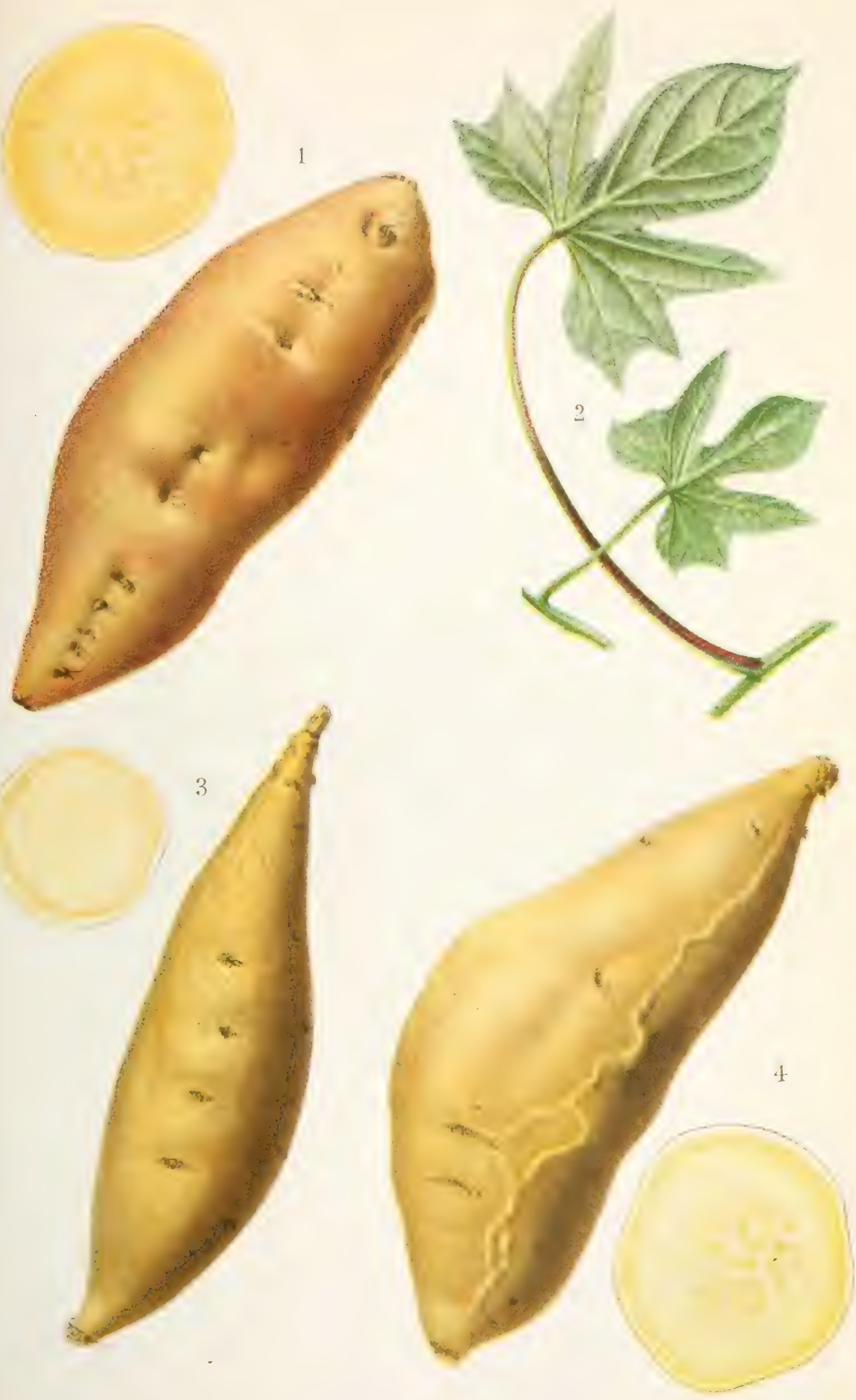

American Varieties of Sweet potatoes. I.

Fig. 1-The Vineless Pumpkin Yam, a representative of the Belmont group, Belmont section. FIG 2-Mature and immature foliage of the Vineless Pumpkin Yam. Fig. 3.-Bunch Candy Yam, a representative of the Belmont group. Bunch section. Fig. 4--Yellow Strasburg, a representative of the Spanish group, Spanish section: a heavy vielder of very irregular potatoes of fair quality. 


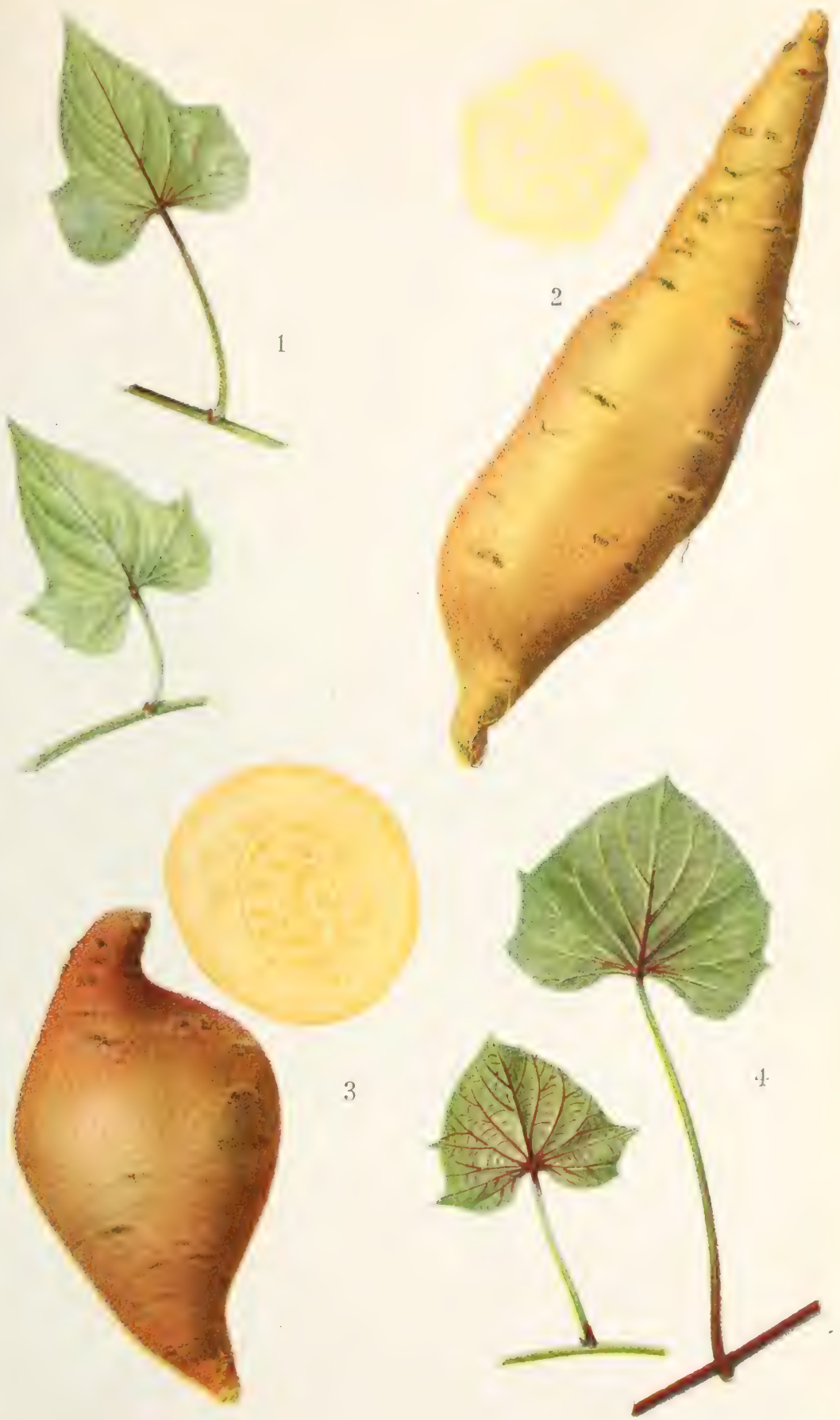

american Varieties of Sweet potatoes. 11.

Fic. 1-Young and old folinge of Yellow Strssburg. FIG, 2,-Triumph, a repre. sentative of the Spanish group, Spanish section; a heavy yielder of roots that are often very. irregular. Fig. 3.-Porto Rico, a representative of the Spanish group. Bermuda section. Fig. 4.-Folinge of Porto Rico, nne of the best varieties. 

on the reins above. green except for a deep-purple stain at the base of the blate and the summit of the petiole. The purple color runs to the latrer veins of the leaf to some extent; petioles green except at upper ent, hatiry fo some extent. Roots white in color, smooth, and regular or veined and ribhed, long cylindrical to fusiform in shape, medium to large in size, and very late in season; flesh yellow or dull grayish white. When baked, only slightly sweet, dry and mealy, and rather firm in texture. Flavor not pronounced.

The Shanghai group contains the following varieties.

(1) Shanghai. (Also called Early Golden and California.)

(2) Minnet "yam."

FLORIDA GROUP.

Vines medium to long, 4 to 10 feet; stems rather coarse and thick, green, smoth or somewhat hairy at the nodes, or they may be hairy all over; leaves entire or toothed, with 6 to 10 low marginal teeth, hairy or smooth, except for scattered hairs on the veins on the upper surface, green except for a deeppurple stain at the juncture of the blade and the petiole. this color passing to the large veins of the leaf and down the petiole a short distance: petiole otherwise sreen and smooth or somewhat hairy : roots light yellow or yellow tinged with salmon; veins when present lighter in color than the rest of the surface, short to long. fusiform in color, of medium to large size, season merlium; flesh wllow or yellow tinged with salmon to dark salmon, but light yellow to dark mange yellow when baked; sweet to very sweet, and sugary, very moist to quitr dry : the texture soft and melting or sometimes rather coarse; flavor good.

The following varieties belong to the Florida group:

(1) Florida. (Also called Arizona Prolific and Providence.)

(2) General Grant Vineless.

(3) Nancy Hall.

\section{SOUTHERN QUEEN GROUP.}

Vines large and vigorous, long, 6 to 12 feet; the stems thick and coarse, dull purple in color. hairy throughout the length, somewhat hairy at the nodes and on new growth, or smooth; leaves shouldered or sometimes entire, slightly hairy above, smooth beneath, green; petiole greenish purple and nearly smooth or hairy (especially at the base). Roots white or light yellow and sometimes very slightly tinged with pink around the upper end, fairly smooth and regular, or somewhat ribbed and veined, globular or short, fusiform in shape or long fusiform; medium to large in size; season medium. Flesh light yellow, sweet, very moist to fairly dry, soft in texture or very fibrous; flavor good.

The following varieties belong to the Southern Queen group:

(1) White "yam."

(2) Southern Queen. (This variety, or slight variations of it, is known under the following names: California "yam," Arkansas Hybrid, Brazilian, Cuban, Common “yam," Hayman, Johnson's Bahama, Kentucky White, McCoy, Polo, Vestal's Newark, Miles "yam." Archers' Hybrid, Hamburg, Caroline Lee, Cullman Cream “yam," Hanover, Catawba White, and Ballinger's Pride.)

\section{PUMPKIN GROUP.}

Vines $10 \mathrm{ng}, 6$ to 15 feet; stems small to average size, green, slightly hairy (especially at the nodes and on new growth) : leaves low. shouldered. or entire with + to 10 low marginal teeth, hairy on the upper surface of the blade and smooth beneath, green; petiole green, slightly hairy (especially near its $71638^{\circ}-22-2$ 
base). Roots rellow, tinged with salmon, fusiform to crlindrical in shape, reined prominentl ${ }_{i}$ and often slightls ribbed. the reins light rellow in color, medium to large in size, season late. Flesh yellow to deep orange-rellow. When baked, sweet to rery sweet. rers moist and soft in texture. flaror distinctly like squash.

The Pumpkin group contains the following varieties:
(1) Pumpkin "yam."
(Early Yellow, or Spanish "yam.")
(2) Norton.
(3) Dooley.
(4) White Gilke.

\section{JERSEY GROUP.}

Yines low and slender to large in growth rers short. 1 to $2 \frac{1}{2}$ feet, or long, 6 to 15 feet; stems vers slender to thick and coarse. green. hairs (especially at the nodes) ; leares shnuldered to entire (both extremes mar be found on the same vine), green, sometimes a rerr slight tinge of purple may be found at the juncture of the blade and the petiole especially in the Rerl Jersey section. smonth or hairs on the upper surface of the blade, slightly hairs, or smooth beneath; petiole green, hairy (especially at the lower encl). Roots red or russet rellow in color, usually rers regular in shape smooth or reined more or less, short to long fusiform or even globular, small to large in size. season early to late; flesh light rellow to dark yellow. Then baked, fairly sweet, usually rery dry and mealy, and quite firm in texture.

The Jerser group contains the rarieties usually found on the northern markets. These may be divided into the following sections:

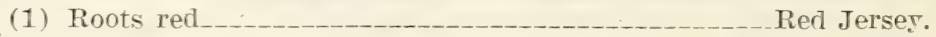

(2) Roots russet yellow.

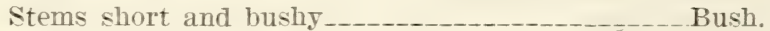

Stems long.

Stems medium to large___________________ Big-Stem Jersey. Stems slender. Yellow Jersey.

Tarieties of the Red Jersey section hare stems rarring from slender to coarse. often fasciated; roots light russet, red, or dark red, medium in size, usually fusiform or oroid. sometimes globular in shape: season medium to late; flesh golden brown. Then baked. sweet. drr, and mealy; quite firm in texture.

The following varieties belong to the Red Jersey section:

(1) Japan Brown.

(2) Red Jersey. (Also called Connelly"s Early Red, Early Red Carolina, Red Nansemond, and Van Ness Red.)

The stems of the Bush section are rerr short, 1 to $2 \frac{1}{2}$ feet, rather thick and coarse. with rers short internodes and crowded leares. the internodes onethird to one-half inch long: leares hairs on the upper surface, but more shining than those of the Yellow Jerser section, usualls entire or slightls shouldered: roots russet rellor, fusiform to oroid in shape, medium in size, season medium; flesh rellow. When baked, the flesh is fairly sweet, drs, and mealy, quite firm in texture.

The Bush section contains but one varietr, the Tineland Bush. (Also called Georgia Buck "yam" and Vineless Bunch Nansemond.)

In the Big-Stem .Jersey section the rines are moderately large growing, long, 6 to 12 feet; stems rather thick and coarse, often fasciated; leares larger than those of the Yellow Jersey section, strongls shouldered to entire. Roots russet rellow, often strongly reined, but otherwise smooth and regular, usualls fusiform in shape, but inclined to become oroic, medium to large in size; season medium, flesh light sellow. When baked, the flesh is usually very dry and mealy and quite firm in texture; flavor chestuutlike. 
The Big-Stem Jersey section contains the following varieties:

(1) Big-Stem Jersey, sometimes caller Florida and Improverl Big Stem.

(2) Philipili.

The Yellow Jersey section has vines that are very small and slencler to mod-

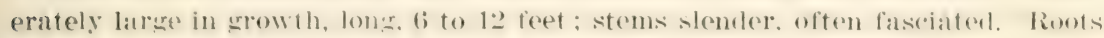
russet yellow, smooth and regular, or with low veins, fusiform or globular in shape, small to melium in size, season medium; flesh light yellow to salmon. When baked, usually very dry and menly and anite firm in textmre.

The Yellow Jersey section contains the following varieties:

(1) Yellow Jersey. (Other names given to this variety or selections of it are the following: Early Bloomer Nansemond, Big Leaf, Larly Carolina, Farly Yellow Jersey, Kelly's, McCoy's Sweets, Red Nose, Nansemond, Yellow Nansemond, Up River, Cedarville.)

(2) Gold Skin.

LIST OF VARIETIES INCLUDED IN THE KEY.

\begin{tabular}{|c|c|c|}
\hline & ge. & \\
\hline Belmont _. & 12 & Porto Rico \\
\hline Big-Stem Jersey_-__-_ & 18 & Pumpkin "yam", \\
\hline unch Candy "yam" & 13 & Purple "yam" or Nigger Ch \\
\hline Sreola & 14 & Red Bermuda \\
\hline Dahomey _._-__ & 15 & Red Brazil \\
\hline Dooley _........ & 17 & Red Jersey \\
\hline Eclinse Sugar "yam". & 1 & Red $\mathrm{S}$ \\
\hline 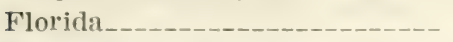 & 1 & Shanghai _._-_ \\
\hline Grint Vineless & 16 & Southern Queen \\
\hline in & 18 & Ticotea__... \\
\hline Gros ( & 1 & $h_{--1}$ \\
\hline Japan & & Bush \\
\hline Key West "yam & 14 & less Pumpkin "yam" \\
\hline Koali $\ldots \ldots$ & 11 & White Gilke_....... \\
\hline Ninnet "yam" & 1 & e Sealy \\
\hline Nancy Hall & 16 & White "yam" -_-_ \\
\hline Norton & 17 & Yellow Jersey \\
\hline me "yam" & 12 & Yellow Spanish \\
\hline$-\infty$ & 18 & Yellow Strasburg \\
\hline Pierson & 13 & Yellow "yam" \\
\hline
\end{tabular}

\section{DESCRIPTIONS OF VARIETIES.}

\section{TICOTEA. (TICOTEA GROUP.)}

Vines large and vigorous, long creeping, 6 to 12 feet; stems green or with a slight tinge of purple at the nodes, nearly smooth; leaves 5 to 7 parted, hairy only along the veins on the upper surface, green except for a deeppurple stain at the hlarle and the summit of the petiole, the latter otherwise green and hairy; roots white, smooth, and regular, usually very long and erlindrical in shape. merlium to large in size, season very late; flesh white, but dull grayish white when hakerl, only slightly sweet, quite dry and mealy; firm in texture.

This is not an important variety.

\section{KOALI. (TICOTEA GROUP.)}

Vines short and stocky; stems green or with a purple tinge at the nodes, smooth or only slightiy hairy at the nodes, coarse: leaves deeply if to 7 lobed; deep-purple stain at the base of the leaf blade, this purple coloring extending 
over veins on the under side of the leaf; petiole with purple stain near the base and at the summit, otherwise green, slightly hairy ; roots white, cylindrical, medium in size, season late; flesh white, but light yellow when baked; mealy; firm in texture, only slightly sweet.

This variety is not grown in this country except in an experimental way.

\section{BELMONT. (BELMONT SECTION, BELMONT GROUP.)}

Vines slender and low, long creeping, 6 to 12 feet; stems light green, hairy; leaves 5 parted with basal lobes inclined to shoulder, hairy above and upon the reins beneath. light green; petiole hairs, green; roots dark yellow with prominent light-yellow veins, fairly smooth and regular, long fusiform in shape, medium in size; season late; flesh golden yellow, but dark yellow when baked, sweet, moist, and soft in texture.

\section{ECLIPSE SUGAR “YAM.” (BELMONT SECTION, BELMONT GROUP.)}

Tines somewhat larger and coarser in growth than is typical for this section, long creeping, 6 to 12 feet; stems hairy, light green; leaf characters similar to those of the Belmont variety except that the blade is larger and the lobes broader; petiole green, hairy; roots light salmon in color, with prominent light-yellow reins, otherwise smooth and regular, fusiform in shape, medium to large, season late; flesh yellow, tinged with salmon. When baked, sweet, moist. and soft in texture.

\section{VINELESS PUMPKIN “YAM." (BELMONT SECTION, BELMONT GROUP.)}

Tines of medium length, 4 to 8 feet; stems green, slightly hairy, especially at the nodes; leaves 5 to 7 parted, hairy above, nearly smooth or slightly hairy upon the reins underneath, green; petiole nearly smooth, green; roots yellow; tinged with salmon, slightly russeted, with a few low, light-yellow reins, fusiform to ovoid, or cylindrical, medium in size, smooth; season late; flesh salmon, with patches of light rellow. When baked, dark yellow to salmon, very sweet and moist; fairly firm in texture.

\section{OLD-TIME “YAM." (BELMONT SECTION, BELMONT GROUP.)}

Vines low and slender in growth, long creeping, 6 to 12 feet; stems green, hairy; leaves 5 to 7 parted, hairy above, nearly smooth beneath, green; petiole green, hairy ; roots light sellow, somewhat russeted, with prominent light-rellow reins, otherwise smooth and regular, fusiform to crlindrical, medium in size; - season late; flesh light yellow. When baked, rery sweet, moist, and soft in texture.

\section{YELLOW “YAM.” (BELMONT SECTION, BELMONT GROUP.)}

Tines low and slender, long creeping, 6 to 12 feet; stems green, hairy; leaves 5 to 7 parted, hairy above and slightly hairy beneath, green; petiole green, hairy (especially at the base) ; roots yellow, tinged with salmon, with low, very light-rellow reins, fusiform in shape, regular, medium in size; season late; flesh yellow, streaked with salmon, salmon ring just under outer skin. When baked, sweet and moist; soft in texture.

\section{WHITE SEALY. (BELMONT SECTION, BELMONT GROUP.)}

Vines medium in length, 4 to 6 feet; stems medium to coarse, green; leaves deeply 5 to 7 lobed, finely cut, green with purple tinge on new growth and at base of petiole, smooth on upper surface and smooth beneath; petioles medium 
length, sreen with tinge of purple at upper end on new growth, smooth ; roots long. cylindrical, yellow to russet yellow, smooth; flesh light yellow, but grayish white when balied: dry and mealy, decided calramel flavor, but not sweet; only fair in quality.

\section{GROS GRANDIA. (BUNCH SECTION, BELMONT GROUP.)}

Vines short to vineless. $1 \frac{1}{2}$ to 3 feet; stems very coarse, green, nodes very ('lose, smooth except for a few hairs on the newer growth; leaves deeply if to 7 lobed or parted, upper surface nearly smooth or slightly hairy, lower surface smooth; petioles smooth or with a few scattered hairs on the new growth, green ; roots long, cylindrical, veins slightly raised, numerous but fine, rose to purplish red in color; Hesh white. When baked, moist and poor in quality.

\section{BUNCH CANDY “YAM." (BUNCH SECTION, BELMONT GROUP.)}

Vines very short and bushy, 1 to $3 \frac{1}{2}$ feet, but medium to vigorous in growth; stems green, nearly smooth, internodes very short, crowding the leaves closely together; leaves 5 to 7 parted, lobes somewhat broader than those of the Belmont variety, hairy above and smooth beneath, light green; petioles nearly smooth, green: roots light yellow, tinged with salmon, slightly russeted, lightyellow reins, small and regular. long spindle or fusiform in shape, small to melium in size; seation late; Hesh light yellow. When baked, sweet and moist; soft in texture.

\section{PIERSON. (YELLOW SPANISH SECTION, SPANISH GROUP.)}

Vines large and vigorous, long creeping, 6 to 15 feet; stems purple in color, hairy; leaves shouldered, hairy only on the veins above, green with a deeppurple stain at the juncture of the blade and the petiole, the latter nearly" smooth, green except at the upuer end ; roots light yellow, strongly ribbed and veined, very rough, fusiform and ovoid in shape, medium to very large; season early ; tlesh cream color, but dull yellow when baked; only slightly sweet, moist to quite dry and mealy; texture firm.

\section{YELLOW STRASBURG. (YELLOW SPANISH SECTION, SPANISH GROUP.)}

Vines large and vigorous, long creeping, 6 to 15 feet; stems purple in color, nearly smooth; leaves shouldered, slightly hairy above, especially on new growtl, green except for a deep-purple stain at the juncture of the blade and the petiole, the latter otherwise green or purple (both colors may appear on the same vine), nearly smooth, roots light yellow, fairly smooth and regular or quite irregular, ovoid or globular in shape, medium to large, season early; flesh dull yellow when baked, sweet, moist, and quite soft in texture.

\section{YELLOW SPANISH. (YELLOW SPANISH SECTION, SPANISH GROUP.)}

Vines moderately large in growth, long creeping, 6 to 12 feet; stems dark furple in color, somewhat hairy; leaves deeply shouldered, smooth or with scattered hairs on the midrib and margin of the leaf, dark green, with purple veins, petiole nearly smooth, purple; roots dull russet yellow, often constricted and crooked, fairly smooth, with no veins, long fusiform to long cylindrical, medium in .size, season late; flesh grayish white; when baked, fairly sweet, moist, and soft in texture. 


\section{TRIUMPH. (YELLOW SPANISH SECTION, SPANISH GROUP.)}

Tines coarse and vigorous, short, 2 to 4 feet, bushy; leaves shouldered, large and thick, hairy on veins of upper surface, smooth beneath; petioles green, with jurple stain at the base of the leaf blade and extending up the veins on the under surface of the leaf; roots medium to long cylindrical in shape, light yellow to russet yellow in color; flesh light yellow, but creamy yellow when baked, medium moist to dry, fairly sweet, and firm in texture. (Pl. V, fig. 2.)

\section{RED BERMUDA. (BERMUDA SECTION, SPANISH GROUP.)}

Vines large and rigorous, long creeping, 6 to 12 feet; stems purple in color, hairy; leares shouldered. slightly hairy abore, green except for a deep-purple stain at the base of the blade and the summit of the petiole, the latter green or purple, nearly smooth; roots deep rose or reddish purple, irregular, strongly ribbed, short fusiform. globular, or oroid in shape, medium to large, season medium; flesh light yellow; but dull yellow when baked; only slightly sweet, dry, and somewhat mealy; firm in texture.

\section{RED BRAZIL. (BERMUDA SECTION, SPANISH GROUP.)}

Tines long to rery long. 6 to 20 feet, vigorous; stems medium coarse, purple in color, hairs, especially at the nodes on new growth; leares shouldered to entire, slightly hairy on the upper surface, smooth beneath, deep-purple stain at the base of the blade; petioles green or purplish green, color running up along the reins on the under side of the leaf, deep purple at summit, slightly hairy at base; roots globular, irregular, surface rose in color; flesh dark yellow; but dark golden yellow when baked; sweet, fairly meals, goorl qualits; season medium to late.

\section{PORTO RICO. (BERMUDA SECTION, SPANISH GROUP.)}

Vines medium to long, 5 to 10 feet; stems coarse, internodes short, reddish purple in color, hairy (especially at the nodes and on young growth); leares shouldered, large in size, green except for a purple stain at the base of the blade and on the reins, slightly hairy on the upper surface, smooth below; petioles medium long, 5 to 8 inches, reddish purple in color, deeper at the base of the leaf blade, color extends to the reins on the lower side of the leaf and also deeper at the base of the petiole; roots light rose to rose in color, fusiform to globular and irregular in shape, smooth; flesh orange rellow to salmon, but dark yellow when baked; moist, very sweet, good quality.

This is one of the most popular rarieties in the South, especially where it is well known. (Pl. V, figs. 3 and 4.)

\section{KEY WEST “YAM." (BERMUDA SECTION, SPANISH GROUP.)}

Vines medium to long, 4 to 10 feet; stems coarse, hairy, dark purple in color. internodes short; leares deeply shouldered, upper surface nearly smooth, lower surface smooth; petioles long, stiff, and erect, smooth except on new growth. which is slightly hairy, purple to pink in color, with heavy purple splash at the base of the leaf bladè; roots medium to long, cylindrical, light rose in color ; flesh cream to yellow, but dark yellow when baked; fine texture, medium moist, quality good.

\section{CREOLA. (BERMUDA SECTION, SPANISH GROUP.)}

Tines long to very long, 8 to 20 feet, vigorous; stems medium to large in size, pink to purple in color, hairy (especially at the nodes) ; leaves deeply shouldered to nearly lobed, green in color, with purple tinge; petioles light red to purple 
in color, dark purple at the summit and at the hase of the leat blade, long and coarse; roots light rose, oblong to fusiform in shape, regular, smooth, no veins, flesh light yellow, hut golden yellow when baked: mealy, swert, fair quality.

\section{RED SPANISH. (RED SPANISH SECTION, SPANISH GROUP.)}

Vines moderately large growing, long, (; to 12 feet; stems dark purple in color, somewhat hatry; leaves deeply shouldered, smooth or with satteresl hairs on the midrib and margin of the blade, dark green with purple veins; petioles purple, smooth; roots dark red in color, smooth and fairly regular, long fusiform to cylindrical in shape, medium to large in size, season late; flesh white with a tinge of purple in the center and near the skin. When baked the Hesh is grayish white, fairly sweet, moist, and soft in texture.

\section{PURPLE "YAM," OR NIGGER CHOKER. (RED SPANISH SECTION, SPANISH GROUP.)}

Vines long, 6 to 15 feet, stoms dark purple in color, somewhat hairy; leaves shouldered. entirely smooth or with seatlered hairs on the midrib and margin of the blate, dark yren with purple veins: petioles nearly smooth, dark purple; roots deep purple in color, smooth and regular, long cylindrical in shape, medium to large; season late; flesh white, often with a tinge of purple beneath the skin and at the center, but dull grayish white when baked; only slightly sweet, very ary and mealy.

\section{DAHOMEY. (RED SPANISH SECTION, SPANISH GROUP.)}

Tines melium to long, 6 to 10 feet: stems green tinged with purple, medium roarse, hairy: leaves entire and heart shaped, tinged with purple around the erige and on the veins of the under surface, hairy on the upper surface, smooth 10 slightly haily below; petioles long. 6 to 10 inches, slender. purple toward the base anc with a deep-purple splash at the base of the leaf blade and the summit of the petiole; roots deep) red to purple, long cylindrical; flesh creamy white, but pale yellow when laked; fine in texture, dry, mealy, fairly sweet, only fair quality.

\section{SHANGHAI. (SHANGHAI GROUP.)}

Vines large and vigorous, medium to long, 6 to 9 feet; stems green, hairy; leaves shouldered or entire, hairy on the veins above and smooth beneath, sreen excent for a deep purple stain at the base of the blade and the summit of the petiole, the latter otherwise green, hairy; roots white fairly smooth and regukar, without veins, fusiform to long cylindrical, very large; season late. When baked, the flesh is grayish white, only slightly sweet, dry, and mealy; fairly firm in texture.

\section{MINNET “YAM." (SHANGHAI GROUP.)}

Vines long, 8 to 16 feet, coarse; stems green, long internorles, hairy; leaves entire and heart shapecl, large, hairy on the upper surface, smooth below; petioles long. smooth except at nodes. sreen with a dark-purple splash at the summit of the petiole and the base of the leaf blade; roots white. fusiform in shape. heavily ribhed or venerl; flesh pale yellow, but light yellow when baked; mealy, dry, poor quality.

\section{FLORIDA. (FLORIDA GROUP.)}

Yines large, rigorous. melium in length. 4 to 9 feet; stems green in color, nearly smooth: leares toothed or entire with 6 to 10 low marginal teeth, hairy above (especially on new leaves) and smooth below, green except for a deep- 
purple stain at the base of the blade and the summit of the petiole; petiole smooth or nearly so, green except at the upper end; roots light yellow in color with lighter yellow reins, fairly smooth and regular, long fusiform in shape, medium in size; season medium to late; flesh light yellow. When baked, sweet, moist, and soft in texture.

\section{GENERAL GRANT VINELESS. (FLORIDA GROUP.)}

Vines medium to large and vigorous, medium in length, 4 to 10 feet; stems green, slightly hairy (especially at the nodes) ; leaves entire or slightly toothed, hairy above, slightls hairs beneath (especially on the veins), green in color, a deep-purple stain at the juncture of the blade and the petiole; petiole green except at the upper end, nearly smooth; roots light salmon, smooth and regular, short fusiform to long fusiform in shape, medium in size, season medium t.) early; flesh gray:sh yellow when baked; sweet, dry, and somewhat mealy; fairly firm in texture.

\section{NANCY HALL. (FLORIDA GROUP.)}

Vines medium in length, 4 to 8 feet; stems somewhat hairy, green; leaves toothed or entire with 4 to 10 low marginal teeth, hairy on the upper surface and slightly hairy or smooth beneath, green except for a reddish purple stain at the juncture of the blade and the petiole, the latter slightly hairy, green except at the upper end; roots yellow, tinged more or less with salmon, reined, or smooth and regular, fusiform in shape, medium to large in size; season early; flesh dark yellow, tinged with salmon. When baked, very sweet, moist and soft in texture; good quality. (Pl. VI, figs. 1 and 2.)

\section{WHITE “YAM." (SOUTHERN QUEEN GROUP.)}

Vines vigorous in growth, long, 5 to 12 feet; stems dull purple, slightly hairs; leaves shouldered or entire, hairy on the veins above, but otherwise smooth. green; petiole nearly smooth, greenish purple; roots yellowish white, with mans low reins, otherwise smooth and regular, fusiform or oblong in shape, medium. to very large in size, season medium; flesh light yellow. When baked, sweet, quite dry, and mealy; texture fairly firm.

\section{SOUTHERN QUEEN. (SOUTHERN QUEEN GROUP.)}

Vines large and rigorous, long. 6 to 12 feet; stems dull purple, slightly hairy (eśpecially at the nodes and on new growth); leaves shouldered or entire, slightly hairy above, green; petiole nearly smooth, greenish purple. Roots white or light yellow, sometimes rery slightly tinged with pink, smooth and regular, few or no reins, fusiform, globular or ovoid in shape, medium to large; season medium; flesh light sellow. When baked, sweet, moist, and soft in texture. (P1. VI, figs. 3 and 4.)

Ballinger's Pride is a strain of Southeri Queen, with roots smaller, longer, fusiform in shape, very smooth.

Catawba White and Catawba Yellow are the same as Southern Queen, but the roots smaller, longer, smooth, and attractive in size and shape.

\section{PUMPKIN "YAM." (PUMPKIN GROUP.)}

Vines moderatel $\nabla$ large growing, long, 6 to 12 feet; stems green, hairy; leaves low, shouldered, hairy only on the upper surface, green; petioles green, hairy; roots yellow, tinged with salmon, mostly irregular with prominent light- 

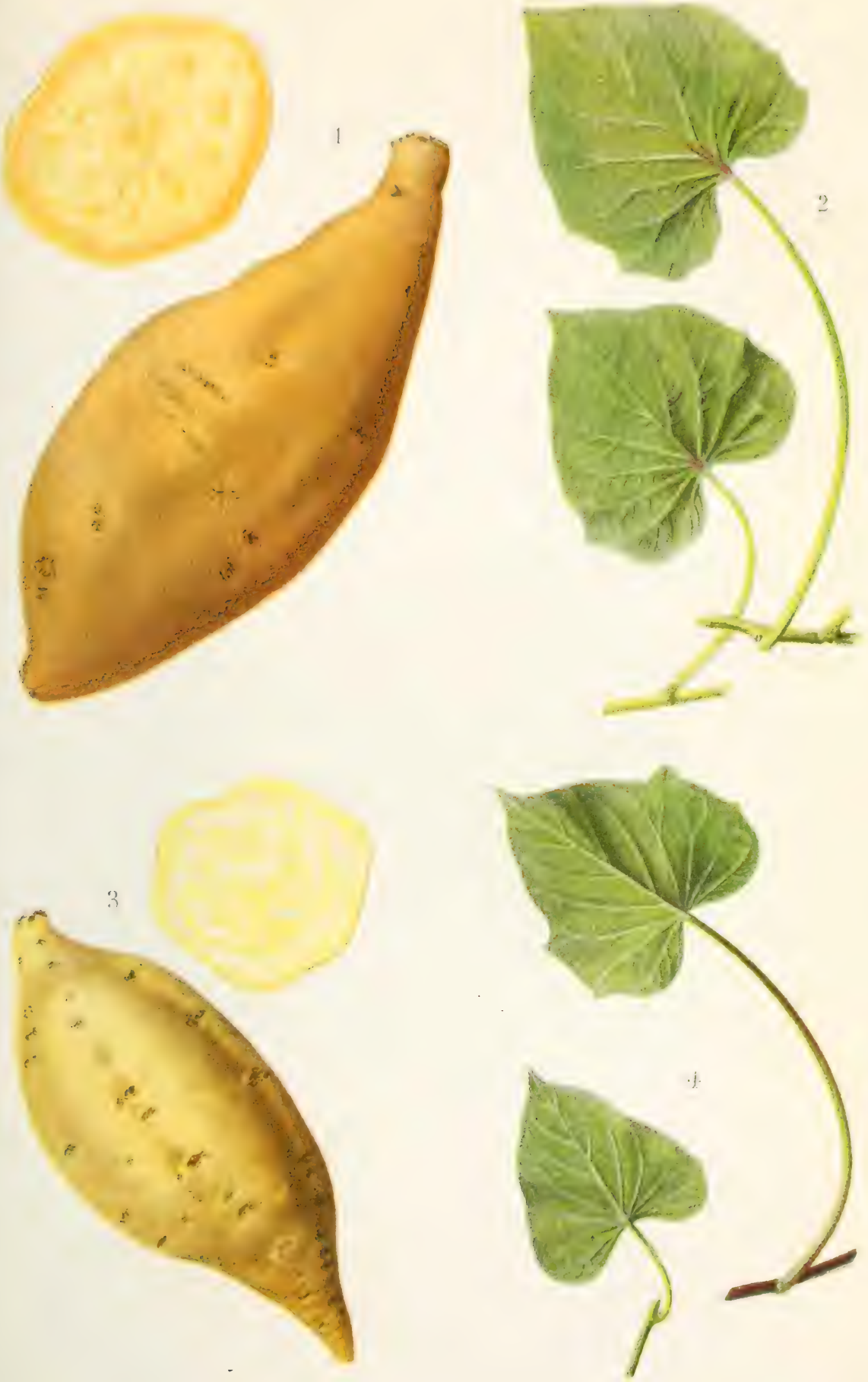

American Varieties of SWeet Potatoes. III.

Fig, 1-Nancy Hall, one of the best varietips of the moist-fleshed type. Fig. 2.-Foliage of Nancy Hall, mature (above) and immature (below). Fig. 3.Southern Queen, heavy yielder of fais quality; known in many sections as the Hayman. Fig. 4.-Young and old folinge of the Southern Queen. 


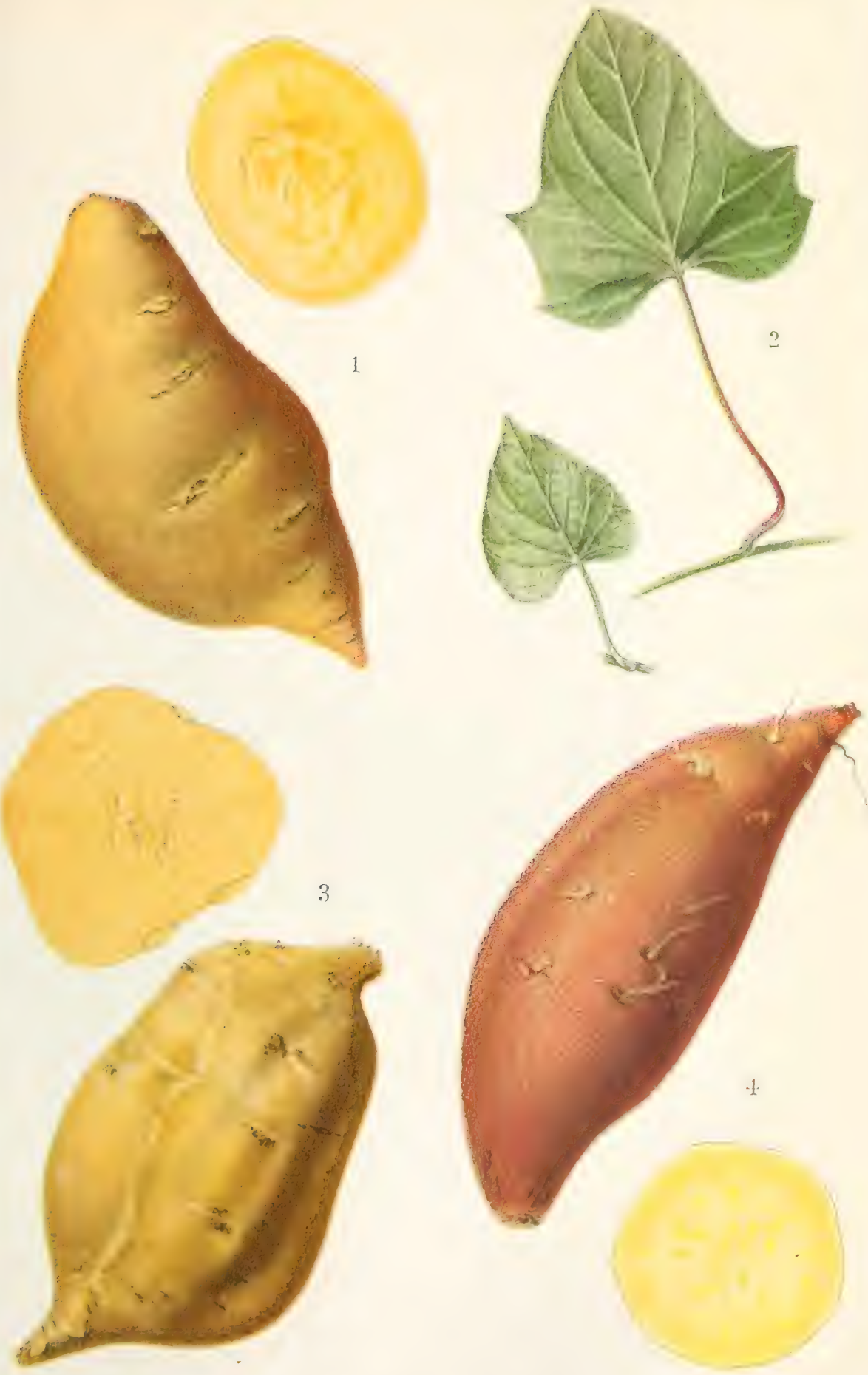

american Varieties of Sweet potatoes. IV.

Fig. 1.-Pumpkin Yam, a representative of the Pumpkin group. Fic. 2.-Foliago if the l'umpkin Yam. mature fabnepl and immature (below). Fir. Dooler, a copular variety and a representative of the Pumpkin gromp. Fin. t Rerl Jersey, a member of the Jersey group. la rgely grown for commercial purposes. 


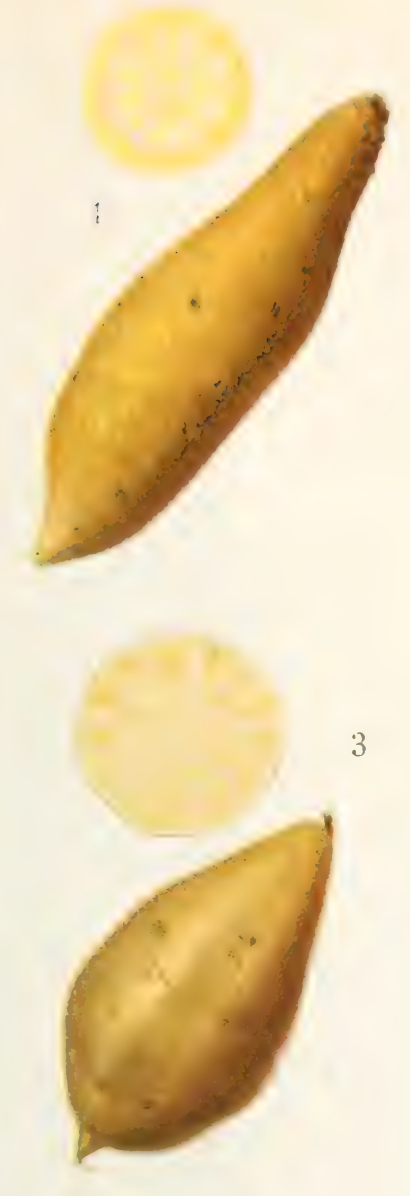

5
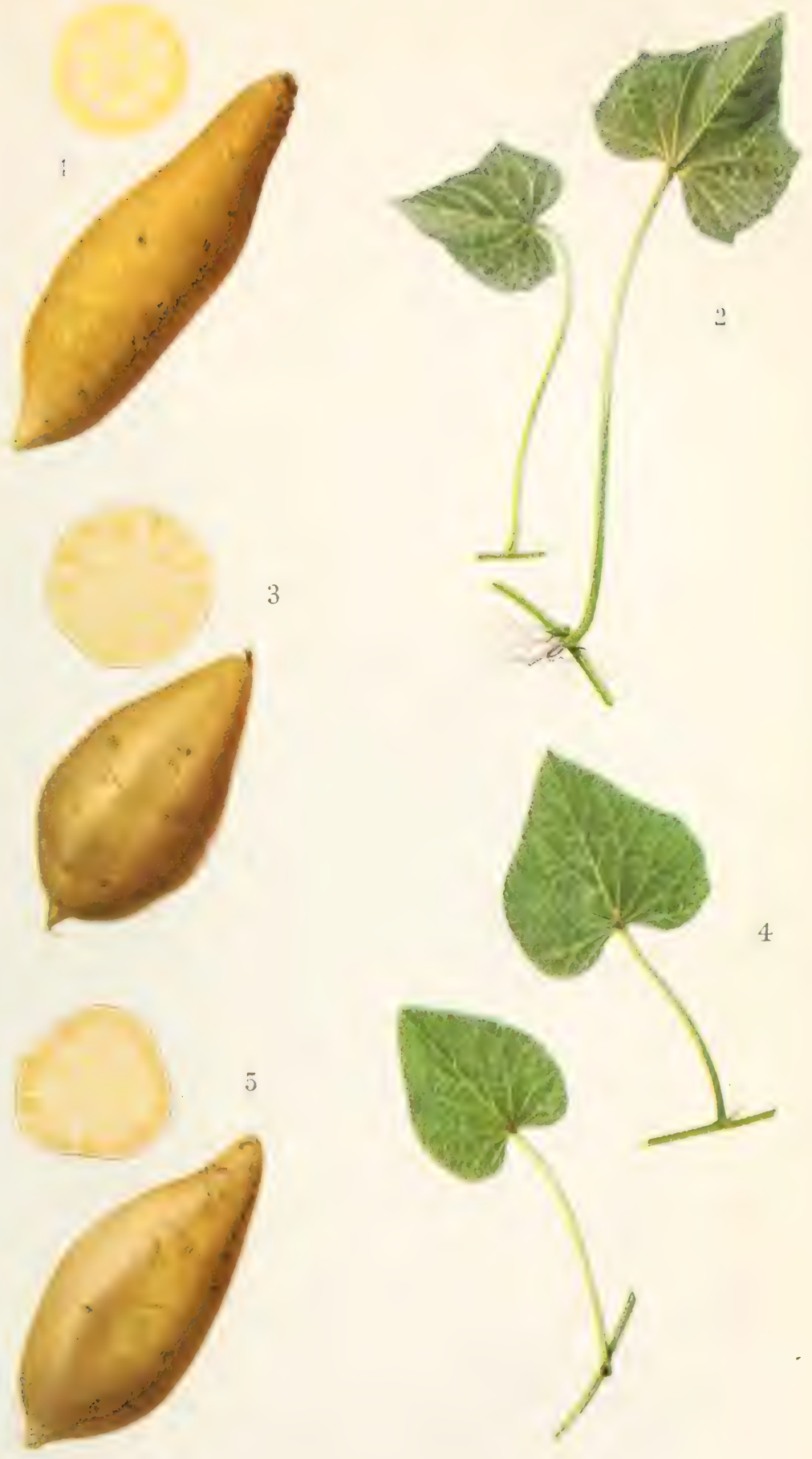

american Varieties of Sweet potatoes. $V$.

Frg. 1.-Big-Stem Jersey, one of the leading commercial varieties. FIG. 2Foliage of the Big-Stem Jergey mature (at right) and immature (at left), Fig. 3.- Yellow Jersey, the leading variety in the Jersey section. Fig. 4.Foliag of Yellow Jersey, fully developed (above) and young leaf (below). FIG. 5.-Gold Skin, a member of the Jersey group; of good quality. 

yellow vains, some smooth and regular with few or no veins, fusiform in shape, medium in size, season late; flesh dark orange-yellow. When baked, very sweet, moist, and soft in texture. (Pl. VII, figs. 1 and 2.)

\section{NORTON. (PUMPKIN GROUP.)}

Vines molerately large growing. long. o 10 12 feet: stems hairy, green, or sometimes with a slight purple tinge; leaves shouldered or entire, with four to six low marginal teeth, hairy on the upper surface and to some extent beneath, green or sometimes with a slight purple tinge on the upper surface; retioles gren, hairy: roots light satmon with light-yellow veins. smooth and regular, fusiform to slightly cylindrical in shape, medium to large; season late; flesh dark yellow. When baked, very sweet and sugary, moist to very moist, soft and melting in texture.

\section{DOOLEY. (PUMPKIN GROUP.)}

Vines lonf to rery long. 10 to 15 feet; stems green, slightly hairy (especially at nodes): leaves shouldered or often entire, green in color, hairy above and smeoth beneath: petioles green, slightly hairy: roots large in circumference, short fusiform in shape, yellow to salmon in color: flesh dark orange. When baked, soft and sweet, squashlike. (Pl. VII, fig. 3.)

\section{WHITE GILKE. (PUMPKIN GROUP.)}

Vines medium short, 3 to 6 feet, or bushy; stems green, coarse, short internodes, hairy (especially at nodes): leaves entire or heart shaped, slightly hairy above, but smooth on the uncler surface; petioles green, smooth, or slightly hairy near the mules: roots white to pale russet yellow, smooth, fusiform in shape: flesh yellow to salmon but a golden yellow when baked: fine in texture, fairly sweet, moist, good quality.

\section{JAPAN BROWN. (RED JERSEY SECTION, JERSEY GROUP.)}

Vines lons, ruming 6 to 15 feet; stems green, hairy, coarse, long internodes; leaves toothed or entire with four low marginal teeth, smooth on the upper surfuce of the leaf, slightly hairy below; petioles long, coarse, hairy, green; roots rexl, long fusiform or slightly cylindrical; flesh white but light yellow when baked; mealy, coarse in texture, fair quality ; season late.

\section{RED JERSEY, (RED JERSEY SECTION, JERSEY GROUP.)}

Vines low and slender in growth, long, 6 to 12 feet; stems green, hairy (especially at the nodes); leaves shouldered, often entire, hairy on the upper surface and smooth beneath, green; petiole green, hairy; roots red in color, fusiform or spindle shaped, snooth and regular or veined to some extent, small to merlium in size; season melium; flesh yellow. When bakerl, fairly sweet, rery dry, and mealy; firm in texture. (Pl. VII, fig. 4.)

\section{VINELAND BUSH. (BUSH SECTION, JERSEY GROUP.)}

Vines vigorous in growth. very short. 1 to $2 \frac{1}{2}$ feet; stems green, hairy, sometimes fasciaterl: numerous leaves, this character resulting from the very short internoles; leaves shouldered or more often entire, hairy above and smooth hentath, green: petioles ereen. slightly hairy: roots russet yellow in color, smoth and regular, fusiform to wroid, not veinerl, medium in size, season early ; flesh yellow. When baked, sweet, dry, and mealy ; firm in texture. 


\section{BIG-STEM JERSEY. (BIG-STEM JERSEY SECTION, JERSEY GROUP.)}

Tines moderately large growing, long, 6 to 12 feet; stems green, hairs; leaves shouldered or entire, hairs abore and smooth beneath, green; petiole hairs, green; roots russet rellow in color, smooth and regular, long fusiform in shape, may be reined or smooth, small to large in size. but larger than Yellow Jersey or Red Jersey, season medium to late; flesh yellow. When baked, sweet, dry, and mealy ; texture firm. (Pl. VIII, figs. 1 and 2.)

\section{PHILIPILI. (BIG-STEM JERSEY SECTION, JERSEY GROUP.)}

Vines rigorous; medium in length, \pm to 8 feet; stems large, green, slightly hairs; leares entire, hairy abore and smooth on lower surface, light green in color; petioles green. slightly hairy at base; roots white or slightly russet yellow in color, flesh white, but pale yellow when baked; dry and meals; poor quality.

\section{YELLOW JERSEY. (YELLOW JERSEY SECTION, JERSEY GROUP.)}

Tines small, slender, long. 6 to 12 feet; stems green, hairs, often fasciated; leares shouldered or entire, hairy only on the upper surface, green: petioles green, hairy; roots dark russet sellow, long or short, fusiform to globular or oroid in shape (two trpes known on the market, one long fusiform and another rers short), smooth or reined; small to medium in size; season medium, flesh rellow. When baked, rery dry and mealy, fairly sweet; texture quite firm. (Pl, VIII, figs. 3 and 4.)

\section{GOLD SKIN. (YELLOW JERSEY SECTION, JERSEY GROUP.)}

Tines medium to long, 6 to 10 feet; slender, hairy (especially at nodes); green in color; leares shouldered or entire (both forms may be found on the same rine), light green, hairy above, slightly hairs beneath; petioles short, slender, hairy, green, except for slight tinge of purple at the base of the leaf blade; roots dark russet rellow, fusiform in shape, smooth and regular; season medium; flesh salmon, but a dark rellow when baked; medium dry and mealy, very sweet; texture firm. (Pl. VIII, fig. 5.)

\section{CHECK LIST OF NAMES USED IN SWEET-POTATO LITERATURE.}

Names appearing in boldface type are recognized varieties; those in italic type are synonyms.

Adams. Synonym of Yellow StrasBURG.

African Bunch.

African Red (probably same as RED Spanish).

Alabama.

Alabama Red (probably same as Porto Rico).

Amarillo.

Archers' Hybrid. Synonym of SouthERN QUFEN.

Archias Hybrid (probably same as SOUTHERN QUEEN).
Arizona Prolific. Synonym of Florida. Arkansas Beauty. Synonym of PIERson.

Arkansas Hybrid. Synonym of SouthERN QUEEN.

Arranca madre.

Bahama or Bahamas (probably same as Southern QueEN).

Bahama "yam" (sometimes called Mexican "yam").

Baker. Synonsm of Triuarph.

Ballinger's Pride. Synonym of SouthERN QUंEEN. 
Barbado. See Barbados.

Barbadoes. See Barbudos.

Barbados.

Barbados Seedlings.

Barbascoa.

Bardos (probably same as Souther. QUFFEN).

Baydus (sometimes known as Barba(loes).

Belmont.

Bensun.

Benson Mammoth (probably same as Benson).

Bermuda (probably same as Rev BerMUDA).

Bermuda Red (probably same as Ren BERMUdA).

Bernuda Sweet.

Bermuda White.

Big Leaf. Synonym of Yet.Low .JERsey.

Big-Leaf Jersey.

Big Stem (probibly same as Big-Stem JERSEY).

Big-Stem Jersey.

Big-Stem Nansemond (probably same as Big-SteM Jersey).

Black.

Black Rock.

Black Spanish. Synonym of RED SPANISH.

Blanca.

Blanco.

Bloomer Nansemond (probably same as YeLLow Jersey).

Boca Sagarto.

Boone Red. See Boone's Rerl.

Boone's Red.

Boone's White.

Bradley "yam."

Brasiliano (probably same as Brazilian).

Brass Cannon.

Brazilian. Synonym of SoutherN Queen.

Brazilian "yam" (probably same as Brazilian: sometimes called White Brazilian).

Bronze.

Bronze Spanish. Synonym of Yellow SPANISH.

Bronze Yellow (probably same as YELLow SPANISH).

Brown Seedling.

Brujo blanco.
Brujo colorado.

Brujo morado.

Buckskin (probably same as Soutrier QUEeN).

Buck "yam."

Bunch Candy "yam."

Bunch Dooley (probably same as DOOLEY).

Bunch "yam." Symonym of BuncH CANDY "YAM."

Busby "yam."

Bush "yam."

Cadalle (probably same as Southern QUEen).

Calubaza.

California, Synonym of SHANGHAI.

California Golden. Synonym of I'IERSON.

California "yam." Synonym of SoutнERN QUEEN.

Caniaguez.

Camarete.

Camarioca.

Camote Silbestre.

Campanilla.

Canal.

Candela.

Carolina.

Carolina Extra Early (probably same as Extra Early Carolina).

Carolina "yam."

Caroline Lee. Synonym of SouTHERN Quenn.

Catawba White. Synonym of SoutHERN QUEeN.

Catawba "yam" (probably same as SoutherN QueEN).

Catawba Yellow. Synonym of SouthERN QUEEN.

Cavitt's Earliest.

Cedarville. Synonym of YExLow JERSEY.

Centauro amarillo.

Centauro colorado.

Chazal.

Chesboro.

Chinese 30 Days.

chinco blanco.

Choker (sometimes called Orleans Red).

Ciclon.

Cienfuegos.

Cinco dedos.

Cluster "yam." 
Colman "yam."

Columbia Yellow.

Common Louisiana "yam" (sometimes called Georgia "yam”).

Common Red.

Common "yam." Synonym of South ERN QUEEN.

Connelly's Early Red. Srnonrm of RED JERSEY.

Cooney.

Creola.

Creole (sometimes called Sugar "yam").

Cuba.

Cuba "yam." Synonym of Red BerIIUDA.

Cúban. Synonym of SOUTHERN QCEen.

Cuban Queen (probably same as SOUTHERN QUEeN).

Cuban "yam."

Cullman Cream "yam" (probably same as Southern QUeen).

Curtis.

Dade County.

Dahomey.

Daris' Enormous.

Davis' Golden Beauty (probably same as Porto Rico).

Delaware (Jersey group, probably Gold SkIN).

Dhamake White.

Disciplinado.

Dog River.

Dooley.

Dooley "yam" (probably same as Dooley).

Dunton's Early. Synonym of PIERSon.

Dunton's Improved. Synonym of BELMONT.

Early Bloomer Nansemond. Synonym of YeLLow Jersey.

Early Bunch "yam" (probably strain of Bunch "yam").

Early California (probably strain of California).

Early Carolina. Synonym of YeLLow JERSEY.

Early Caroline (probably strain of YELLOW JeRSEY).

Early General Grant. Synonym of PIERson.

Early Golden. Synonym of Shanghai. Early Golden " yam."
Early Jersey (probably same as YeLLOW JERSEY).

Early Light Jersey (probably same as Yellow JeRsey).

Early Nansemond (probably same as YeLLOW JERSEY).

Early Peabody (probably strain of PEABODY.

Early Red.

Early Red Carolina. Synonym of RED JERSEY.

Early Rirers.

Early Peabody (probably strain of TrIUMPh).

Early Yellow. Synonym of Pumpkis "YAM."

Early Yellow Bunch.

Early Yellow Carolina (probably same as YeLLow JeRSEY).

Early Yellow Jersey. Synonym of YELLOW JERSEY.

Early Yellow Nansemond (probably same as YeLLow JeRsey).

Early York.

Eclipse Sugar "yam."

Ely.

Enano.

Enormous.

Extra Early Accomac.

Extra Early Carolina.

Extra Early Caroline (probably same as YELLOW JeRSEY).

Extra Early Golden. Synonym of YELLOW STRASBURG.

Extra Early Red Caroline (probably same as RED JERSEY).

Extra Red Carolina (same as ReD JERSEY).

Familia.

Fire Brass.

Florida.

Florida (sometimes applied to BIGStem Jersey).

Florida Bunch.

Florida Bunch "yam" (probably same as SOUTHERN QUEEN).

Florida "yam." See Florida.

Forked-Leaf Pumpkin (probably same as PUMPKIN "YAM").

Forty in a Hill.

Fullerton Yellow "yam."

Furbelow Yellow "yam." 
General Grant (probably same as Sotтhern Q('weN).

General Grant Vineless.

Georgin. Synonym of BELMONT.

Georgia Buck (probably same as (ieorgia Buck "yamo").

Georgia Burk "yam." Synomym of VINEIAND BUSH.

(ieorgia Sugar "yam."

Georgia "yam" (sometimes callerl common Louisiana "yam.").

Gold Coin. Synonym of Piekson.

Gold Coin Bunch "ram" (mohably same as BUNCH CANDT "YAM").

\section{Gold Skin.}

Golden. Benuty. Synonym of I'oвto Rico.

Golden Coin (probably same as SouthERN QUEEN).

Golden Queen.

Golden Skin. Synonym of Pierson.

Golden Strasshurg (probably same as Yellow Strasbur(i).

(rovernor.

Gros Grandia.

Guinero.

Hache.

Haiti " yam" (sonetimes called MusGROVE).

Hall. See NANCY HaLd.

Halomai "yam."

Halonaipu.

Hamburg. Synonym of SoUTHERN QUEEN.

Hannover. See Hanover.

Hanover. Synonym of SoutherN QUEEN.

Hanover (sometimes, called RoYaL of HANover).

Hanover "yam." See HANover.

Harman (sometimes called White "YAM").

Hayman. Synonym of SoutherN QLEeN.

Hayti (probably of the Spanish group ).

Hayti Spanish (probably of the Spanish group).

Heckler.

Heckler "yam."

Hen and Chickens. -

Hornero.

Horton "yam."
III:1 Imแ1.

IIuffs.

Ilunt's Red.

Thumai.

Improved Bin stem. Synomym of BusiSTEM JERSEY.

Improved Big-Stem Jersey. See BIGS'TEM JERSEY.

Improved Dooley "yam." S'ee Dom, sy. Improved Providence. See Provibence. India Red.

Indian Red.

Isla de Pinos.

Japan Brown.

Japanese "yam" (probably of the Belmont group).

Java No. 1. (Introductions.)

Java No. 2. (Introductions.)

Java No. 3. (Introductions.)

Java No. 4. (Introductions.)

Java No. 5. (Introductions.)

Jersey (probably same as Yellow JERSEY ).

Jersey Red (probably same as RED JERSEY).

Jersey Sweet (probably of the Jersey group-YeLLow JeRsey).

Jersey Yellow (probably same as YeLLOW JERSEY).

Jerusalem.

Jerusalem " yam."

Jewell "yam."

Jiguani.

John Burnet.

Johnson's Bahama. Synonym of SOUTHERN QUEEN.

Kala.

Kapo.

Kauaheahe.

Kawelo.

Kelly's. Synonym of Yellow JERser. Kentucky White. Synonym of SoutHERY QUEEN.

Key West.

Key West " yam."

Key West "yam" (sometimes applied to Porto Rico).

Koali.

Laiakona.

Lexington " yam."

Light Early Red.

Little Bunch. 
Little-Stem Jersey (probably same as YELLOW JERSEY).

I.ouisiana.

Louisiana "yam."

McCoy. Synonym of Southern Queen. IICCoy's sweet. Synonym of Yellow JERSEY.

McDonald.

Maleta.

Mamey.

Mameya.

Mameyana.

Mameyita.

Mani.

Mani blanco.

Mani colorado.

Mani morado.

Manila.

Manila colorado.

Marada.

Martinica blanco.

Martinica morado.

Martinico.

Matejita.

Matojito.

Matojo.

Merced Sweet (same as Jersey SWEET).

Mexican (sometimes called BaHAMA "YAM").

Miami.

Miles "yam." Synonym of SoutherN Queen.

Minnet " yam."

Minnie White.

Minute "yam."

Miseria.

Mississippi Yellow (probably same as TELLOW JERSEY.

Molly Malone.

Mono Negro.

Morado.

Morning Glory.

Morris Sweet Seed.

Muffard.

Muffard "yam."

Mulato.

Blullihan. Synonym of NANCY HALL.

Murray

Murray Extra Early.

Murrey's Extra Early.

Murry's Extra Early.

Muscatine.

Musgrove (sometimes called HaITI

$$
\text { "YAM"). }
$$

Myers' Early.

Myers' “yam."

Nancy Hall.

Nansemond. Synonym of YeLLow JERSEY.

Nansemond Improved (probably same as YeLLOW JeRSEY.

Nansemond Red (probably same as RED JERSEy.

Nansemond White.

Negrito.

Negro Choker (probably same as Nigger Choker).

Negro Killer (probably same as Nigger CHOKER).

Newfoundland.

New Jer'sey (probably same as Yellow JERSEY.

New Jersey Nansemond (probably same as YeLLow JeRsEy.).

New Nansemond (probably same as YELLOW JERSEY).

Nigger Choker. Synonym of PURPLE "YAM."

Nigger Killer (probably same as Nigger CHOKer).

Nina.

North Carolina " yam."

Northern Yellow.

Norton.

Norton "yam" (probably same as Norton).

Notch-Leaf Bunch "yam."

Nueva Gerona.

Oebi Hitam.

Oebi Kang Kong.

Oebi Radjit.

Old Maurice.

Old-Time " yam."

Orange.

Oriente.

Orleans Red (s o metimes called CHOKer).

Orum.

Padisha.

Padishah.

Pancho.

Pancho del Sol.

Pan con Vino.

Papa:

Papa blanco.

Paragon.

Patasaw " yam." 
Pattusal "yam."

Peabody.

rearson (probably same as Prerson).

Pepper's Choice.

Peruvian.

Peruvian "yam."

Philipili.

Phillipin "yam" (sometimes called

Larly Yellow Bunch).

Picarlito.

Pierson.

Pikonui.

Pilipili.

Pimento (sometimes called Yellow I'IMExto).

Poland.

Polo. Symonym of Southern Queen.

Fool's "yam."

Poor Land (probably same as PORELAND).

Poplar Spanish (probably same as Popular Root Spanish).

Popular Root (sometimes called SouthERN QUeEN).

Popular Root Spanish.

Poreland. Synonym of Red Bermuda. Porto Rico.

Porto Viejo.

Pride of Kansas.

Prolific. Synonym of Bunch Candy "YAM."

Proridence. Synonym of Florida.

Providential.

$\mathrm{Pu}$.

Pumpkin.

Pumpkin Early Yellow "yam."

Pumpkin "yam."

Purple "yam."

Queen.

Queen of the South (probably same as Southern Queen).

Queen of the West.

Rayo.

Red Beans.

Red Bermuda.

Red Brazil.

Red Brazilian.

Red Jersey.

Red Nancemond (probably same as RED JERSEY).

Red Nansemond. Synonym of RED JERSEY.
Red Nose. Synonym of YeLLOW JER$\mathrm{SEY}$.

Red Providence.

Red sealy.

Red-skinnerl Yellow "yam."

Red Spanish.

Red "Yam."

Redlding.

Relampago.

Rockport.

Rooserelt.

Rositas.

Royal Sweet Potato of Hanover. See Hanover.

Running Dooley (probably same as DOOLEX).

Sabanilla blanco.

Sabanilla colorado.

Sadies Prolific.

St. Domingo.

San Domingo (sometimes called W Hite San Domingo).

San Fernando.

San Juan.

Saln Pedro blanco.

San Pedro colorado.

San Roque.

Santa Maria.

Santa Rita.

Santiago.

Santiaguero.

Sapotillo.

Shaker Yellow.

Shanghai (sometimes called CALIForNIA).

Short Vine Yellow "yam."

Sopa en vino.

Southern Nansemond (probably same as Yellow Jersey).

Southern Queen.

Southern Red.

Southern Red "yam."

Southern "yam."

Southern Yellow.

Southern Yellow "yam.

Spanish.

Spanish Bunch.

Spanish Poplar.

Spanish Poplar Root.

Spanish Red (probably same as RED SPANISH).

Spanish White. 
Spanish "yam." Synonym of PUMPKIN "YAM."

Split Leaf (sometimes known as Georgia "yam").

Strasboury.

Strasburg.

Strassberg.

Strassburg.

Strousburg.

Sugar.

Sugar "yam."

Sulla.

Tennessee.

Tennessee Notchleaf ( sometimes called IELLOW "YAM").

Tennessee Notched Leaf.

Tennessee "yam."

Texas "ram."

Thegamia Red.

Thegamia White.

Thompson's Favorite.

\section{Ticotea.}

Tolman Spanish.

Tornasol.

Trinidadian No. 1.

Trinidadian No. 2.

\section{Triumph.}

True Brass.

True Parson Prince.

Tuna.

Up River. Synonym of Yellow JERSEY.

Up Rivers (probably same as Yellow JERSEY).

Vaca.

Van Ness Red.

Van Nest Red. Synonym of Red JeRSEY.

Vestal's Newark. Synonym of SouthERN QUEEN.

Vestal's New Arkansas Yellow " yam."

Vincetoman " yam."

Vincentonia.

Vineland Bunch.

Vineland Bunch "yam."

Vineland Bush.

Vineland Sweets.

Vineless. Synonym of Bunch Candy "YAM."

Vineless Beach.

Vineless Bunch.

Vineless Bunch Nansemond (probably same as Vineland Bunch).

Vineless Bunch "yam."

Vineless Pumpkin " yam."
Vineless. "yam."

Vinerlonian.

Vino tinto.

Violette Blanche.

Violette Rouge.

Virg nia Nansemond.

Virginia Red Nose.

Vuelta amajo.

Tuelta arriba.

Vuelta bajero.

Test India “ yam."

White Barbaloes.

White Belmont. Sזnonsm of $\pi$ Hite

$$
\text { " YАM." }
$$

White Bermuda.

White Brazilian (sometimes called BRAZILIAN "YAM").

White California.

White Columbia.

White Gilk.

White Gilke.

White Gilkes.

White Nansemond (sometimes called

Arkansas Beauty).

White Providence.

White St. Domingo (sometimes called

San Domingo).

White Sealy.

White Seedling.

White Skinner.

White Spanish.

White Vineless.

White West India.

White "yam."

Willets' Red Skin.

"Yams" (sometimes called SoutHERN QUEEN).

Yellow (sometimes called YeLLow "YAM").

Yellow Barbadoes.

Yellow Bean.

Yellow Belmont. Synonym of YELLOW "YAM."

Yellow Bermuda.

Yellow Buckskin.

Yellow Columbia.

Yellow Jersey.

Yellow Mauritius.

Yellow Nancemond (probably same as YELLOW JERSEY).

Yellow Nansemond. Synnnym of YELLOW JERSEX. 
Yellow Pimento (sometimes called Pinento).

Yellow Providence.

Yellone Red. Syuonym of Ren BERMLDA.

Yellow Rind.

Yellow Spanish.
Yellow Strasburg.

Yellow Straussberg. See Yexmow Strasizurg.

Yellow Sugar.

Yellow Trinidatian.

Yellow " yam."

Yema de huevo. 


\section{BIBLIOGRAPHY OF SWEET-POTATO LITERATURE.}

(1) Ames, C. T.

1914. Report of the work done at Holly Springs branch experiment station, 1913. In Miss. Agr. Exp. Sta. Bul. 165, 32 p., 13 fig.

(2) Austin, C. F.

1909. Report of the Department of horticulture. In Cuba. Estac. Cent. Agron. 2d Rept., 1905/8, Eng. ed., p. 58-67, pI. 13- 17 B (on $7 \mathrm{pl}$.).

(3) Barrett Company, Agricultural Department.

[1918] Sweet Potatoes and Yams. 15 p., 11 fig. New York. [Pub.] no. 19.

(4) Beattie, W. R.

1908. Srveet potatoes. U. S. Dept. Agr., Farmers' Bul. 324, 39 p., 24 fig. Reprinted 1917.

(5) Bennett, R. L.

1891. Sweet potatoes, tests of varieties, analysis of varieties. . In Ark. Agr. Exp. Sta. 3rd Ann. Rpt., 1890, p. 123-128.

(6) - and IRBY, G. B.

1894. Experiments at Northeast sub-station. Sweet potatoes. In Ark. Agr. Exp. Sta. Bul. 31, p. 16-19.

(7) Blount, A, E.

1894. Agriculture and horticulture. In N. Mex. Agr. Exp. Sta. 4th Ann. Rpt., 1892/93, p. 6-9.

(8) Brown, James B.

1886. Reference Book explanatory of Brown's improved above-ground Storehouse for the Keeping over Winter of Fruit, Sweet and Irish Potatoes . . . with a prize Essay on the Propagation, Cultivation, and Preservation of the Sweet Potato . . 20 p. McMinnville, Tenn.

(9) BRunk, T, L.

1889. Report of the horticulturist. In Tex. Agr. Exp. Sta. 1st Ann. Rpt., 1888, p. 35-45.

(10) Bunnette, F. H.

1894. Sweet potatoes. La. Agr. Exp. Sta. Bul. 30, p. 1050-1089, fig. 1-35, A-C.

(11) - Watson, Eugene, and Stubbs, William C.

1896. Horticulture. Results of the year 1895. La. Agr. Exp. Sta. Bul. 42 , p. 1501-1544.

(12) Carver, George W.

1906. Saving the sweet potato crop. Ala. Tuckegee Exp. Sta. Bul. 10, 14 p., 6 fig.

(13) 1915. Possibilities of the sweet potato in Macon County, Alabama. Ala. Tuskegee Exp. Sta. Bul. 30, 22 p., 8 fig.

(14) Clute, O.

1897. Report of the director. In Fla. Agr. Exp. Sta. Ann. Rpt., 1896, p. $5-17$. 
(15) Craig, John.

1900. Notes on vegetables. Iowa Agr. Exp. Sta. Bul. 47, p. 306-337, $18 \mathrm{fig}$.

(16) Crow, Curnow.

[1915] Sweet Potato Culture for the Southern Planter . . . 103 p., 2 fig., 12 pl. Seville, Ga.

(17) DEBAUN, R. W.

[1919] Sweet potato culture and storage in New Jersey. N. J. Agr. Exp. Sta. Circ. 114, 31 p., 18 fig.

(18) Duggar, J. F.

1597. S'weet potatoes: culture and uses, U. S. Dept. Agr., Farmers' Bul. 26, 30 p., 4 tig.

(19) 1892. Methods of keeping sweet potatoes. S. C. Agr. Exp. Sta. Bul. $5,8 \mathrm{p}$.

(20) EARLE, F. S.

1896. Fruits and vegetables on the Gulf coast. Miss. Agr. Exp. Sta. Bul. 37, p. 109-134.

(21) FAilyer, G. H., and Willard, J. T.

1891. Composition of some feeding stuffs. In Kans. Agr. Exp. Sta. Bul. 32, p. 225-228.

(22) Fitz, James.

1886. Sweet Potato Culture... with a Chapter on the Chinese Yam.

New and enl. ed. 86 p., 2 fig. New York.

(23) Forbes, R. H.

1908. A lesson in diversified farming. Ariz. Agr. Exp. Sta. Timely hints for farmers 69,8 p. Reprinted in Bul. 60, p. 417-426. 1909.

(24) García, Fabián.

1908. Report of the horticulturist. In N. Mex. Agr. Exp. Sta. 18th Ann. Rpt., 1906/07, p. 31-46.

(25) 1909. Sweet potato culture. N. Mex. Agr. Exp. Stu. Bul. 70,35 p., 8 fig.

(26) Groth, B. H. A.

1911. The Sweet Potato. 104 p., 54 pl. New York. (Contrib. Bot. Lab. Univ. Penn., v. 4, no. 1.)

(27) HaRDiN, M. B.

189.). Chemist's report. In S. C. Agr. Exp. Sta. 8th Ann. Rpt, [1894]/95, p. 51-63.

(28) Hester, C. E.

1918. North Louisiana experiment station. In Lal. Agr. Fxp. Sta. 30th Ann. Rpt., 1917, p. 17-21.

(29) Higgins, J. E.

1911. Report of the horticulturist. In Hawaii Agr. Exp. Sta. Ann. Rpt., [1909]/10, p. 25-40, 4 fig., pl. 1-2.

(30) HunN, C. E.

1590. Report of acting horticulturist. In N. I. State Agr. Exp. Sta. 8th Ann. Rpt., 1889, p. 298-336.

(31) 1891. Report of acting horticulturist. In N. Y. State Agr. Exp. Sta. 9th Ann. Rpt., 1890, p. 257-308, 15 pl. 
(32) INgersolt, C. L.

1891. Farm notes for 1891. Nebr. Agr. Exp. Sta. Bul. 19, 12 p., 3 pl. Also in 5th Ann. Rpt. 1891, p. 203-214, 1892.

(33) Jaffa, M. E., and Curtis, Marvin.

1894. California sweet potatoes. In Calif. Agr. Exp, Sta. Rpt. of Work, 1892/94, p. 219-225.

(34) Johnson, T. C., and RosA, J. T., jr.

1916. Sweet potato culture. Va. Truck Exp. Sta. Bul. 19, p. 385-415, fig. 87-99. Literature, p. 415.

(35) KeITT, T. E.

1909. Sweet potato work in 1908. S. C. Agr. Exp. Sta. Bul. 146, 21 p.

(36) 1912. Sweet potato investigation. S. C. Agr. Exp. Sta. Bul. 165, 43 p.

(37) KrnMan, C. F.

1918. Report of the horticulturalist. In Porto Rico Agr. Exp. Sta. Rpt., 1917, p. 20-24, pl. 2-3.

(38) Lee, Jordan G.

1889. Report of the North Louisiana experiment station . . . at Calhoun, La. for 1889. La. Agr. Exp. Sta. Bul. 27, p. 455-497.

(39) 1891. Results of 1890 obtained on the North Louisiana Experinrent Station, Calhoun. La. Agr. Exp. Sta. Bul. 8, ser. 2, p. 167214.

(40) 1892. Results of 1891 obtained on the North Louisiana Experiment Station, Calhoun. La. Agr. Exp. Sta. Bul. 16, ser. 2, p. 425484.

(41) 1893. Report of results for 1892, at Calhoun. La. Agr. Exp. Sta. Bul. 21 , ser. 2 , p. $607-656$.

(42) MCDonNell, C. C.

1908. The manufacture of starch from sweet potatoes. 'S. C. Agr. Exp. Sta. Bul. 136, 50 p., 5 fig., 4 pl. (in .text)

(43) [MCKAY, A. B.]

1889. Horticultural work. Sweet potatoes. In Miss. Agr. Exp. Sta. 1st Ann. Rpt., 1888, p. 47-49.

(44) Massey, W. F.

1890. The work of the horticultural dirision. In N. C. Agr. Exp. Sta. Bul. 72, p. 3-10.

(45) 1890. Tests of garden regetables. In N. C. Agr. Exp. Sta. Bul. 74, p. 3-17.

(46) 1895. Trucking in the South ... N. C. Agr. Exp. Sta. Bul. 112, p. $27-95$.

(47) Mooring, D. C.

1914. Sweet potatoes. Okla. Agr. Exp. Sta. Cire. 25, 12 p., 2 fig.

(48) Morgan, H. A., and Burnette, F. H. .

1893. Report of the horticulturist. In La. Agr. Exp. Sta. Bul. 22, ser. 2 , p. 679-720.

(49) — and Ross, B. B.

1892. Sweet potatoes. La. Agr. Exp. Sta. Bul. 13, ser. 2, p. 311-342, 16 fig.

(50) NEAL, J. C.

1893. Sweet potatoes. In Okla. Agr. Exp. Sta. Bul. 4, p. 7-8. 
(51) Nesbit, D. M.

1901. Sweet potatoes. U. S. Dept. Agr., Farmers' Bul. 129, 40 p.

(52) NEWMAN, C. L.

1902. Sweet potato experiments. Ark. Agr. Exp. Sta. Bul. 72, p. $33-43$.

(53) NEWMAN, J. S.

1887. Experiments with sweet potatoes and sugar cane, 1876 [i. e. 1886]. Ala. [Col.] Exp. Sta. Bul. 5, 12 p.

(54) Price, J. C. C.

1917. Harvesting and storing sweet potatoes. Ala. [Col.] Agr. Exp. Sta. Bul. 197 , p. 85-102, 15 pl.

(55) Price, R. H.

1893. Sweet potatoes. Tex. Agr. Exp. Sta. Bul. 28, p. 327-346, 25 fig., $1 \mathrm{pl}$.

(56) 1895. Sweet potatoes. In Tex. Agr. Exp. Sta. Bul. 36, p. 609-629, 15 fig.

(57) [1896] Sweet Potato Culture for Profit . . vii, 107 p., 62 fig. Dallas, Tex.

(58) Richmond, E. S., and Cory, A. F.

1890. Horticultural department. In Ark. Agr. Exp. Sta. 2nd Ann. Rpt., 1889, p. 82-104, 14 fig.

(59) Robinson, JAmes S.

1895. Small fruits, vegetables and field corn. Md. Agr. Exp. Sta. Bul. 33 , p. 115-134.

(60) Roig, Juan T., and Fortun, Gonzalo M.

1916. Las variedades cubanas de boniato. Cuba Estac. Exp. Agron. Bol. 33,76 p., 32 pl.

(61) Sсотт, ЈонN M.

[1909] Report of animal industrialist. In Fla. Agr. Exp. Sta. Rpt., [1908]/09, p. xv-xxiv, 3 fig.

(62) [1910] Report of animal industrialist. In Fla. Agr. Exp. Sta. Rpt., [1909]/10, p. xiv-xxiv.

(63) 1915. Report of animal industrialist. In Fla. Agr. Exp. Sta. Rpt., [1913]/14, p. xviii-xxix.

(64) Shinn, Charles H.

1894. Southern California station . . . In Calif. Agr. Exp. Sta. Rept. of Work, 1S92/94, p. 415-424, 1 pl.

(65) SHTVER, F. S.

1897. The sweet potato as a starch producer. S. C. Agr. Exp. Sta. Bul. 28, $15 \mathrm{p}$.

(66) 1897. The determination of starch in the sweet potato. S. C. Agr. Exp. Sta. Bul. 30, 11 p.

(67) 1901. Sweet potato... S. C. Agr. Exp. Sta. Bul. 63, 37 p.

(68) SMITH, JARED G.

[1890] Field experiments for 1889. Nebr. Agr. Exp. Sta. Bul. 12, 63, p. Also in 4th Ann. Rpt. [1890], p. 267-329, 1891.

(69) SMith, Longfield.

1920. Sweet potatoes. In Virgin Isl. Agr. Exp. Sta. Rpt. 1919, p. 16, fig. 2 on pl. 2 . 
(70) Speth, Gustave.

1891. Experiments in the culture of sweet potatoes, tomatoes, cabbage, etc. In Ga. Agr. Exp. Sta. Bul. 11, p. 22-46.

(71) 1892. [Irish potatoes, sweet potatoes, tomatoes, forage plants.] Ga. Agr. Exp. Sta. Bul. 17, p. 165-198.

(72) Starnes, Hugh N.

1894. Sweet potatoes. Ga. Agr. Exp. Sta. Bul. 25, p. 127-161, 35 fig., $1 \mathrm{pl}$.

(73) Strahan, C. Morton.

1889. Analyses of cattle foods. Ga. Agr. Exp. Sta. Bul. 4, p. 62-71.

(74) Stubbs, William C., Burnette, F. H., and Watson, Eugene.

1895. Horticulture. Results of the year 1894. La. Agr. Exp. Sta. Bul. 36, ser. 2, p. 1237-1286, 1 fig.

(75) 1898. Report for 1896 and 1897 of the horticultural department of State experiments stations. La. Agr. Exp. Sta. Bul. 52, ser. 2, p. 283-332.

(76) Stuckey, H. P.

1914. Sweet potatoes. Culture, storing, and studies in fertilizing. Ga. Agr. Exp. Sta. Bul. 107, p. 83-112, 24 fig.

(77) Tenbrook, JoHn W.

1860. The Sweet Potato Culturist . . 96 p., 3 fig. Rockville, Ind.

(78) Voorhees, E. B., and Street, Јонn P.

1895. Experiments with fertilizers upon sweet potatoes. In N. J. Agr. Exp. Sta. 15th Ann. Rpt., 1894, p. 102-114.

(79) Watrous, Frank.

1889. Report of Arkansas Valley experiment station. In Colo. Agr. Exp. Sta. 2nd Ann. Rpt., 1889, p. 113-128.

(80) White, H. C.

. 1891. Analyses of feeding stuffs. In Ga. Agr. Exp. Sta. Bul. 13, p. 61-65.

(81) Wicks, W. H.

1915. Sweet potato culture in Arkansas. Ark. Agr. Exp. Sta. Bul. 124, 31 p., 21 fig.

ADDITIONAL COPIES

OF THIS PUBLICATION MAY BE PROCURED FROM

THE SUPERINTENDENT. OF DOCUMENTS

GOVERNMENT PRINTING OFFICE

WASHINGTON, D.C.

$\mathrm{AT}$

30 CENTS PER COPY 


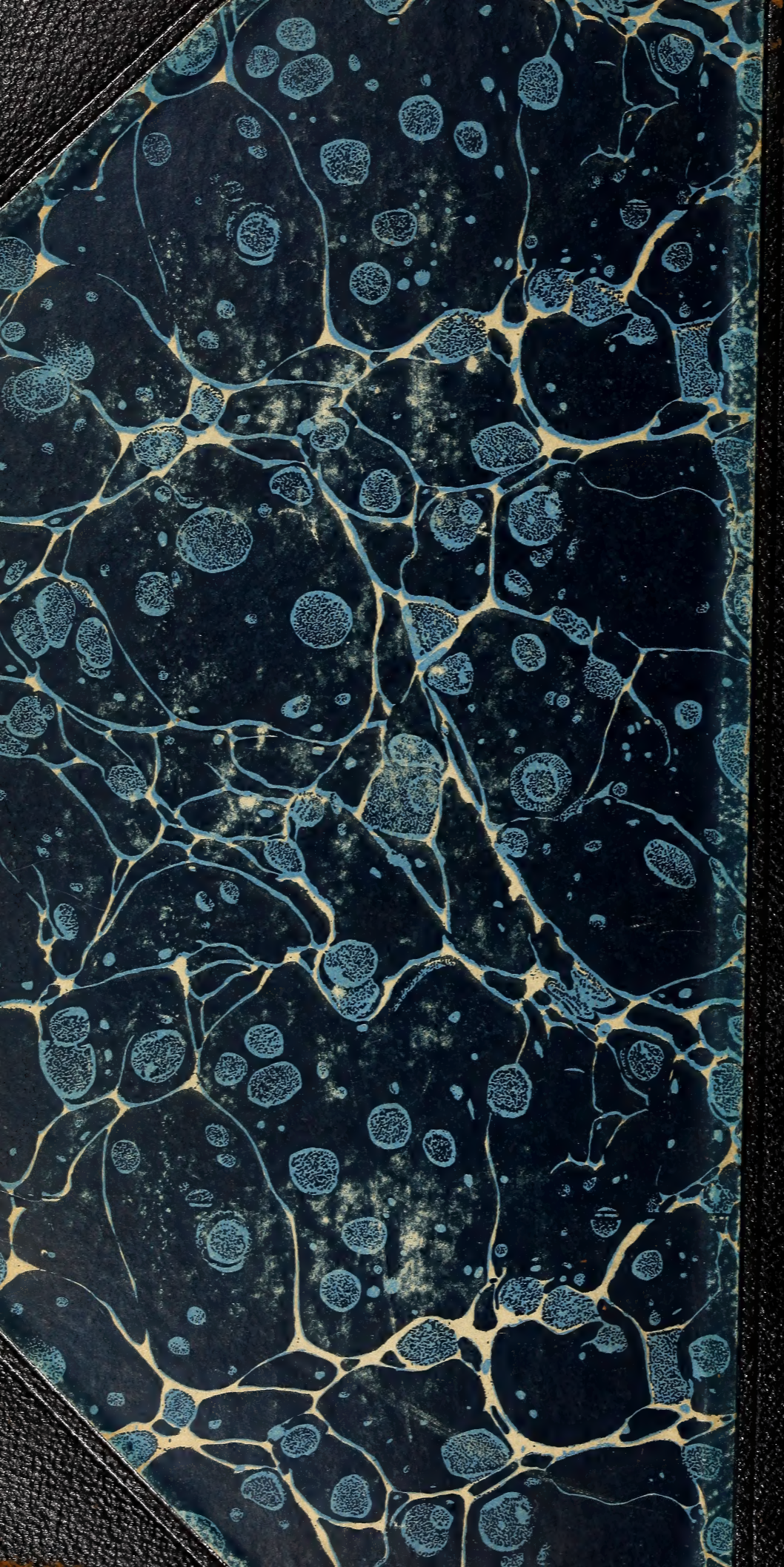

